\title{
Ground-level nitrogen dioxide concentrations inferred from the satellite-borne Ozone Monitoring Instrument
}

\author{
L. N. Lamsal, ${ }^{1}$ R. V. Martin, ${ }^{1,2}$ A. van Donkelaar, ${ }^{1}$ M. Steinbacher, ${ }^{3}$ E. A. Celarier, ${ }^{4}$ \\ E. Bucsela, ${ }^{5,6}$ E. J. Dunlea, ${ }^{7,8}$ and J. P. Pinto 9 \\ Received 30 July 2007; revised 9 April 2008; accepted 23 May 2008; published 28 August 2008.
}

[1] We present an approach to infer ground-level nitrogen dioxide $\left(\mathrm{NO}_{2}\right)$ concentrations by applying local scaling factors from a global three-dimensional model (GEOS-Chem) to tropospheric $\mathrm{NO}_{2}$ columns retrieved from the Ozone Monitoring Instrument (OMI) onboard the Aura satellite. Seasonal mean OMI surface $\mathrm{NO}_{2}$ derived from the standard tropospheric $\mathrm{NO}_{2}$ data product (Version 1.0.5, Collection 3) varies by more than two orders of magnitude $(<0.1->10 \mathrm{ppbv})$ over North America. Two ground-based data sets are used to validate the surface $\mathrm{NO}_{2}$ estimate and indirectly validate the OMI tropospheric $\mathrm{NO}_{2}$ retrieval: photochemical steady-state (PSS) calculations of $\mathrm{NO}_{2}$ based on in situ $\mathrm{NO}$ and $\mathrm{O}_{3}$ measurements, and measurements from a commercial chemiluminescent $\mathrm{NO}_{2}$ analyzer equipped with a molybdenum converter. An interference correction algorithm for the latter is developed using laboratory and field measurements and applied using modeled concentrations of the interfering species. The OMI-derived surface $\mathrm{NO}_{2}$ mixing ratios are compared with an in situ surface $\mathrm{NO}_{2}$ data obtained from the U.S. Environmental Protection Agency's Air Quality System (AQS) and Environment Canada's National Air Pollution Surveillance (NAPS) network for 2005 after correcting for the interference in the in situ data. The overall agreement of the OMI-derived surface $\mathrm{NO}_{2}$ with the corrected in situ measurements and PSS- $\mathrm{NO}_{2}$ is $-11-36 \%$. A larger difference in winter/spring than in summer/fall implies a seasonal bias in the OMI $\mathrm{NO}_{2}$ retrieval. The correlation between the OMI-derived surface $\mathrm{NO}_{2}$ and the ground-based measurements is significant (correlation coefficient up to 0.86) with a tendency for higher correlations in polluted areas. The satellite-derived data base of ground level $\mathrm{NO}_{2}$ concentrations could be valuable for assessing exposures of humans and vegetation to $\mathrm{NO}_{2}$, supplementing the capabilities of the ground-based networks, and evaluating air quality models and the effectiveness of air quality control strategies.

Citation: Lamsal, L. N., R. V. Martin, A. van Donkelaar, M. Steinbacher, E. A. Celarier, E. Bucsela, E. J. Dunlea, and J. P. Pinto (2008), Ground-level nitrogen dioxide concentrations inferred from the satellite-borne Ozone Monitoring Instrument, J. Geophys. Res., 113, D16308, doi:10.1029/2007JD009235.

\footnotetext{
${ }^{1}$ Department of Physics and Atmospheric Science, Dalhousie University, Halifax, Nova Scotia, Canada.

${ }^{2}$ Also at Atomic and Molecular Physics Division, Harvard-Smithsonian Center for Astrophysics, Smithsonian Astrophysical Observatory, Cambridge, Massachusetts, USA.

${ }^{3}$ Empa-Swiss Federal Laboratories for Materials Testing and Research, Laboratory for Air Pollution/Environmental Technology, Dübendorf, Switzerland.

${ }^{4}$ NASA GSFC, SGT, Inc., Greenbelt, Maryland, USA.

${ }^{5}$ NASA Goddard Space Flight Center, Greenbelt, Maryland, USA.

${ }^{6}$ Now at SRI International, Menlo Park, California, USA.

${ }^{7}$ Department of Earth, Atmospheric and Planetary Sciences, Massachusetts Institute of Technology, Cambridge, Massachusetts, USA.

${ }^{8}$ Now at Cooperative Institute for Research in Environmental Sciences, University of Colorado at Boulder, Boulder, Colorado, USA.

${ }^{9}$ U.S. EPA, National Center for Environmental Assessment, Research Triangle Park, North Carolina, USA.
}

Copyright 2008 by the American Geophysical Union. 0148-0227/08/2007JD009235\$09.00

\section{Introduction}

[2] Nitrogen dioxide $\left(\mathrm{NO}_{2}\right)$ plays a central role in tropospheric chemistry [Logan, 1983; Finlayson-Pitts and Pitts, 1986] and is toxic to biota. Major sources of nitrogen oxides $\left(\mathrm{NO}_{x}=\mathrm{NO}+\mathrm{NO}_{2}\right)$ are combustion, soils, and lightning. Several epidemiological studies have shown consistent associations of long-term $\mathrm{NO}_{2}$ exposure with decreased lung function and increased risk of respiratory symptoms [Ackermann-Liebrich et al., 1997; Schindler et al., 1998; Panella et al., 2000; Smith et al., 2000; Gauderman et al., 2000, 2002]. Strong associations exist between $\mathrm{NO}_{2}$ and nonaccidental mortality in daily time series studies [Steib et al., 2003; Burnett et al., 2004; Samoli et al., 2006]. $\mathrm{NO}_{2}$ concentrations are also highly correlated with other pollutants either emitted by the same sources or formed through complex reactions in the atmosphere [e.g., Brook et al., 
2007]. Complete spatial coverage of ground-level $\mathrm{NO}_{2}$ measurements are needed for exposure assessment.

[3] Stations in the current $\mathrm{NO}_{2}$ monitoring network are sparse and unevenly spaced. Large regions of the United States and Canada lack $\mathrm{NO}_{2}$ measurements. Epidemiologic studies of health risks of $\mathrm{NO}_{2}$ are impaired by insufficient observations in clean versus polluted areas. The instrument most commonly used for routine measurements of $\mathrm{NO}_{2}$ is a chemiluminescence analyzer equipped with a molybdenum converter, a measurement technique which exhibits significant interference from other reactive oxidized nitrogencontaining species $\left(\mathrm{NO}_{z}\right)$ such as peroxyacetyl nitrate (PAN) and $\mathrm{HNO}_{3}$ [Winer et al., 1974; U.S. Environmental Protection Agency, 1975; Grosjean and Harrison, 1985; Fehsenfeld et al., 1987; Demerjian, 2000; Dunlea et al., 2007; Steinbacher et al., 2007]. Surface concentrations of $\mathrm{NO}_{2}$ inferred from satellite remote sensing would complement existing ground-based networks by extending spatial coverage and by being specific to $\mathrm{NO}_{2}$.

[4] Satellite observation of tropospheric $\mathrm{NO}_{2}$ columns began in 1995 with the Global Ozone Monitoring Experiment (GOME-1) [Burrows et al., 1999], and is continued with the SCanning Imaging Absorption spectroMeter for Atmospheric CHartographY (SCIAMACHY) [Bovensmann et al., 1999], Ozone Monitoring Instrument (OMI) [Levelt et al., 2006b, 2006a], and GOME-2 [Callies et al., 2000]. Retrievals of tropospheric $\mathrm{NO}_{2}$ columns from GOME and SCIAMACHY have been used to demonstrate the close relationship between land surface $\mathrm{NO}_{x}$ emissions and tropospheric $\mathrm{NO}_{2}$ columns [Leue et al., 2001; Martin et al., 2003a, 2006; Jaeglé et al., 2005; Zhang et al., 2007]. Observations of a weekly pattern in GOME tropospheric $\mathrm{NO}_{2}$ columns with significant reductions on weekends [Beirle et al., 2003], diurnal variation in $\mathrm{NO}_{2}$ columns driven by emissions and photochemistry [Boersma et al., 2008a], and a large increase in tropospheric $\mathrm{NO}_{2}$ columns over eastern China inferred from GOME and SCIAMACHY [Richter et al., 2005; van $\operatorname{der} A$ et al., 2006] demonstrate the capability of observing air pollution from space. Petritoli et al. [2004] and Ordóñez et al. [2006] found a significant correlation between in situ $\mathrm{NO}_{2}$ measurements and GOME tropospheric $\mathrm{NO}_{2}$ columns. Airborne measurements in the southeastern United States reveal that $\mathrm{NO}_{2}$ in the boundary layer can make a dominant contribution to the $\mathrm{NO}_{2}$ tropospheric column over polluted regions [Martin et al., 2004a; Bucsela et al., 2008]. Each of these studies clearly suggests that the satellite tropospheric $\mathrm{NO}_{2}$ column retrievals are closely related to ground-level $\mathrm{NO}_{2}$ concentrations.

[5] Validation of satellite observations of tropospheric $\mathrm{NO}_{2}$ columns is needed in a range of environments over all seasons. Recent comparisons of tropospheric $\mathrm{NO}_{2}$ columns from the OMI standard product (Version 1.0.0) with observations reveal a low bias of $14 \%$ versus an ensemble of aircraft measurements [Bucsela et al., 2008], of $25 \%$ versus Brewer measurements at NASA Goddard [Wenig et $a l ., 2008$ ], and of 15-30\% versus a suite of ground-based remote sensing and aircraft measurements [Celarier et al., 2008]. All three manuscripts describe concerns with their data sets that motivate additional validation activities. A few hundred ground-based in situ $\mathrm{NO}_{2}$ monitoring stations take regular measurements across North America. Comparison of OMI-derived surface $\mathrm{NO}_{2}$ concentrations with these ground-based measurements would provide indirect validation of OMI $\mathrm{NO}_{2}$ columns.

[6] This paper presents an approach to estimate groundlevel $\mathrm{NO}_{2}$ concentrations from tropospheric $\mathrm{NO}_{2}$ columns retrieved from OMI. The method involves the use of model profiles from a global 3-D model (GEOS-Chem). The method extends that of Liu et al. [2004] and van Donkelaar et al. [2006] who estimated ground-level fine particulate matter $\left(\mathrm{PM}_{2.5}\right)$ concentrations from satellite retrievals of aerosol optical depth. In section 2 , we provide a brief account of the OMI tropospheric $\mathrm{NO}_{2}$ column retrieval and the GEOS-Chem model. In situ surface $\mathrm{NO}_{2}$ measurements are described in section 3 where we present two case studies to illustrate the interference of in situ $\mathrm{NO}_{2}$ data measured by the commercial chemiluminescent $\mathrm{NO}_{2}$ analyzer equipped with a molybdenum converter, and develop a method to correct for interference in the chemiluminescent $\mathrm{NO}_{2}$ measurements. Here we also assess $\mathrm{NO}_{2}$ concentrations estimated from simultaneous measurements of $\mathrm{NO}$ and $\mathrm{O}_{3}$ using a photochemical steady-state (PSS) calculation. Section 4 presents our approach to derive ground-level $\mathrm{NO}_{2}$ concentrations from OMI which are compared with the corrected in situ data and the PSS-NO $\mathrm{NO}_{2}$ in section 5.

\section{Observation and Model}

\subsection{OMI Tropospheric $\mathrm{NO}_{2}$ Columns}

[7] The Dutch-Finnish OMI instrument onboard the Earth Observing System (EOS) Aura satellite launched on July 15,2004 offers greatly enhanced spatial (up to $13 \times 24 \mathrm{~km}^{2}$ ) and temporal (daily global coverage) resolution as compared to its predecessors. The Aura satellite [Schoeberl et al., 2006] passes over the equator in a sun-synchronous ascending polar orbit at 13:45 local time and over North America around 13:00 local time. We use the OMI standard product (Version 1.0.5, Collection 3) available from the NASA Goddard Earth Sciences (GES) Data Active Archive Center (http://disc.sci.gsfc.nasa.gov/data/datapool/OMI/). We focus on the year 2005 when in situ $\mathrm{NO}_{2}$ measurements are available for the United States and Canada. The nearreal-time $\mathrm{OMI} \mathrm{NO}_{2}$ product [Boersma et al., 2008b] was not available for 2005. Detailed descriptions of the algorithm for the standard $\mathrm{OMI} \mathrm{NO}_{2}$ data product are given in Boersma et al. [2002], Bucsela et al. [2006], and Celarier et al. [2008]. In brief, the standard algorithm uses the Differential Optical Absorption Spectroscopy (DOAS) technique [Platt, 1994] to determine the slant column densities by nonlinear least squares fitting in the 415-465 nm window. The slant column represents the integrated abundance of $\mathrm{NO}_{2}$ along the average photon path through the atmosphere. This is followed by the determination of initial vertical column densities by dividing the slant column densities by an unpolluted air mass factor calculated using a single mean unpolluted $\mathrm{NO}_{2}$ profile. To compute air mass factors in polluted regions, the algorithm uses a geographically gridded set of annual mean polluted profiles obtained from a GEOS-Chem simulation [Martin et al., 2003b]. A background $\mathrm{NO}_{2}$ field is determined by applying masks over regions where tropospheric $\mathrm{NO}_{2}$ column abundances are high, smoothing the remaining regions, and conducting a zonal planetary wave analysis up to wave-2. The tropo- 
spheric $\mathrm{NO}_{2}$ column for a given OMI ground pixel is determined from information on the initial vertical column density, the background $\mathrm{NO}_{2}$ field outside the masked areas, and the air mass factors, estimated according to the viewing parameters. Parameters include viewing geometry, $\mathrm{NO}_{2}$ profile shape, and the pressure and reflectivity of clouds and terrain. The cloud information is obtained from the OMI cloud $\mathrm{O}_{2}-\mathrm{O}_{2}$ algorithm [Acarreta et al., 2004].

[8] Significant error sources in the retrieval of the tropospheric $\mathrm{NO}_{2}$ column are associated with the slant column densities, the air mass factor, and with the separation of the stratosphere and troposphere. The air mass factor errors arise primarily from uncertainties in cloud interference, surface albedo, aerosols, and profile shape [Martin et al., 2002, 2003a; Boersma et al., 2002, 2004]. The overall error in the OMI vertical column density for clear and unpolluted conditions is estimated to be $5 \%$, but reaches up to $50 \%$ in the presence of pollution and clouds [Boersma et al., 2002]. The stripes affecting the slant columns in the swath direction in Version 1.0.0 have been greatly reduced in Version 1.0.5 due to an improved dark current correction in the Collection 3 Level 1B processing [Dobber et al., 2008].

[9] The horizontal resolution of OMI decreases toward the edges of the swath by a factor greater than 10 . To reduce spatial averaging, we exclude the ground pixels at swath edges that correspond to a pixel size of more than $50 \times$ $24 \mathrm{~km}^{2}$. We include only cloud-free scenes with a cloud radiance fraction threshold of 0.3 . We calculate area-weighted averages of OMI tropospheric $\mathrm{NO}_{2}$ columns and bin them onto a $0.1^{\circ} \times 0.1^{\circ}$ grid.

\subsection{Simulation of $\mathrm{NO}_{2}$ From GEOS-Chem}

[10] The estimation of ground-level $\mathrm{NO}_{2}$ concentrations from OMI tropospheric $\mathrm{NO}_{2}$ column observations requires information on the tropospheric $\mathrm{NO}_{2}$ profile. For this purpose we use the GEOS-Chem global three-dimensional model of tropospheric chemistry [Bey et al., 2001] at $2^{\circ} \times 2.5^{\circ}$, version 7-03-06 (www.as.harvard.edu/chemistry/trop/geos). Such a model is also useful to correct for $\mathrm{NO}_{z}$ interference of $\mathrm{NO}_{2}$ measured with molybdenum converters.

[11] The GEOS-Chem simulation is driven by assimilated meteorological data from the Goddard Earth Observing System (GEOS-4) at the NASA Global Modeling and Assimilation Office (GMAO). Data for profiles at 55 levels in the vertical extending from the surface to $0.01 \mathrm{hPa}$ of atmospheric variables have 6-hour temporal resolution. Data for surface variables and mixing depths are given every three hours. About 16 levels are in the troposphere, including 5 levels below $2 \mathrm{~km}$.

[12] The model includes a detailed simulation of tropospheric ozone- $\mathrm{NO}_{x}$-hydrocarbon chemistry as well as of aerosols and their precursors [Bey et al., 2001; Park et al., 2004]. The aerosol and gaseous simulations are coupled through the formation of sulfate and nitrate, the $\mathrm{HNO}_{3} / \mathrm{NO}_{3}^{-}$ partitioning of total inorganic nitrate, and heterogeneous aerosol chemistry including uptake of $\mathrm{N}_{2} \mathrm{O}_{5}$ by aerosols [Evans and Jacob, 2005]. The $\mathrm{NO}_{x}$ emissions for the United States are from the EPA 1999 National Emission Inventory [U.S. Environmental Protection Agency, 2001]. Climatological biomass burning emissions are based on the Along Track Scanning Radiometer (ATSR) fire observations [Duncan et al., 2003]. Soil $\mathrm{NO}_{x}$ emissions are computed using a modified version of the algorithm of Yienger and Levy [1995] with the canopy reduction factors described by Wang et al. [1998]. The midlatitude lightning $\mathrm{NO}_{x}$ source is 1.6 $\mathrm{Tg} \mathrm{N} \mathrm{yr}{ }^{-1}$ following Martin et al. [2006] and Hudman et al. [2007].

[13] Several previous studies have used GEOS-Chem to interpret in situ measurements of reactive nitrogen [ $\mathrm{Li}$ et al., 2004; Wang et al., 2004; Hudman et al., 2004, 2007; Martin et al., 2006] as well as observations of tropospheric $\mathrm{NO}_{2}$ columns from satellite instruments [Martin et al., 2003a, 2004b, 2006, 2007; Jaeglé et al., 2005; Guerova et al., 2006; Sauvage et al., 2007; Wang et al., 2007b, 2007a; Boersma et al., 2008a, 2008b; Bucsela et al., 2008]. GEOS-Chem simulations generally agree to within $30 \%$ of measured $\mathrm{NO}_{x}, \mathrm{HNO}_{3}$, and PAN over eastern North America [Martin et al., 2006; Hudman et al., 2007; Singh et al., 2007]. We conduct simulations for the year 2005 following an 8-month spin up. The model output is sampled between 12:00 and 14:00 local time for analysis of the concurrent OMI data over the United States and Canada.

\subsection{Comparison of OMI Tropospheric $\mathrm{NO}_{2}$ Columns With Model}

[14] We initially compare OMI tropospheric $\mathrm{NO}_{2}$ columns with the GEOS-Chem simulation for 2005 over the United States and Canada.

[15] Figure 1 shows seasonal mean tropospheric $\mathrm{NO}_{2}$ columns from OMI and GEOS-Chem. The high-resolution data in Figure 1 (first row) reveal relatively high values in many urban areas such as Los Angeles, San Francisco, Phoenix, Denver, Houston, Dallas, Chicago, Toronto, and the northeast U.S. corridor. Figure 1 (second and third rows) show OMI and GEOS-Chem $\mathrm{NO}_{2}$ columns mapped onto the same grid at $2^{\circ} \times 2.5^{\circ}$ resolution. Both show large-scale pollution over eastern North America. Both exhibit a similar seasonal pattern with a summer minimum that reflects the shorter $\mathrm{NO}_{x}$ lifetime. Monthly mean modeled and observed tropospheric $\mathrm{NO}_{2}$ columns over the United States and southern Canada $\left(25^{\circ} \mathrm{N}\right.$ to $55^{\circ} \mathrm{N}, 70^{\circ} \mathrm{W}$ to $\left.115^{\circ} \mathrm{W}\right)$ are well correlated spatially and temporally $(\mathrm{r}=0.83, \mathrm{~N}=4896)$. Figure 1 (fourth row) shows the seasonal difference between the modeled and retrieved tropospheric column. A clear seasonal bias exists over eastern North America. The winter mean OMI tropospheric column over the United States and southern Canada is $32 \%$ lower than the corresponding value from GEOS-Chem. The seasonal mean OMI tropospheric columns are higher than the GEOS-Chem values by $29 \%$ in spring, $45 \%$ in summer, and $20 \%$ in fall. We use groundbased in situ measurements to examine these seasonal biases.

\section{Ground-Level In Situ Measurements}

[16] Hourly in situ measurements of $\mathrm{NO}_{2}, \mathrm{NO}$, and $\mathrm{O}_{3}$ are obtained from the U.S. Environmental Protection Agency's Air Quality System (AQS) and Environment Canada's National Air Pollution Surveillance (NAPS) network [Demerjian, 2000]. First we discuss the measurements of $\mathrm{NO}_{2}$ by commercial analyzers. Then we examine two approaches to infer ground-level $\mathrm{NO}_{2}$ concentrations: by correcting for interference in the $\mathrm{NO}_{2}$ measurements made with the molybdenum converter, and by calculating $\mathrm{NO}_{2}$ 

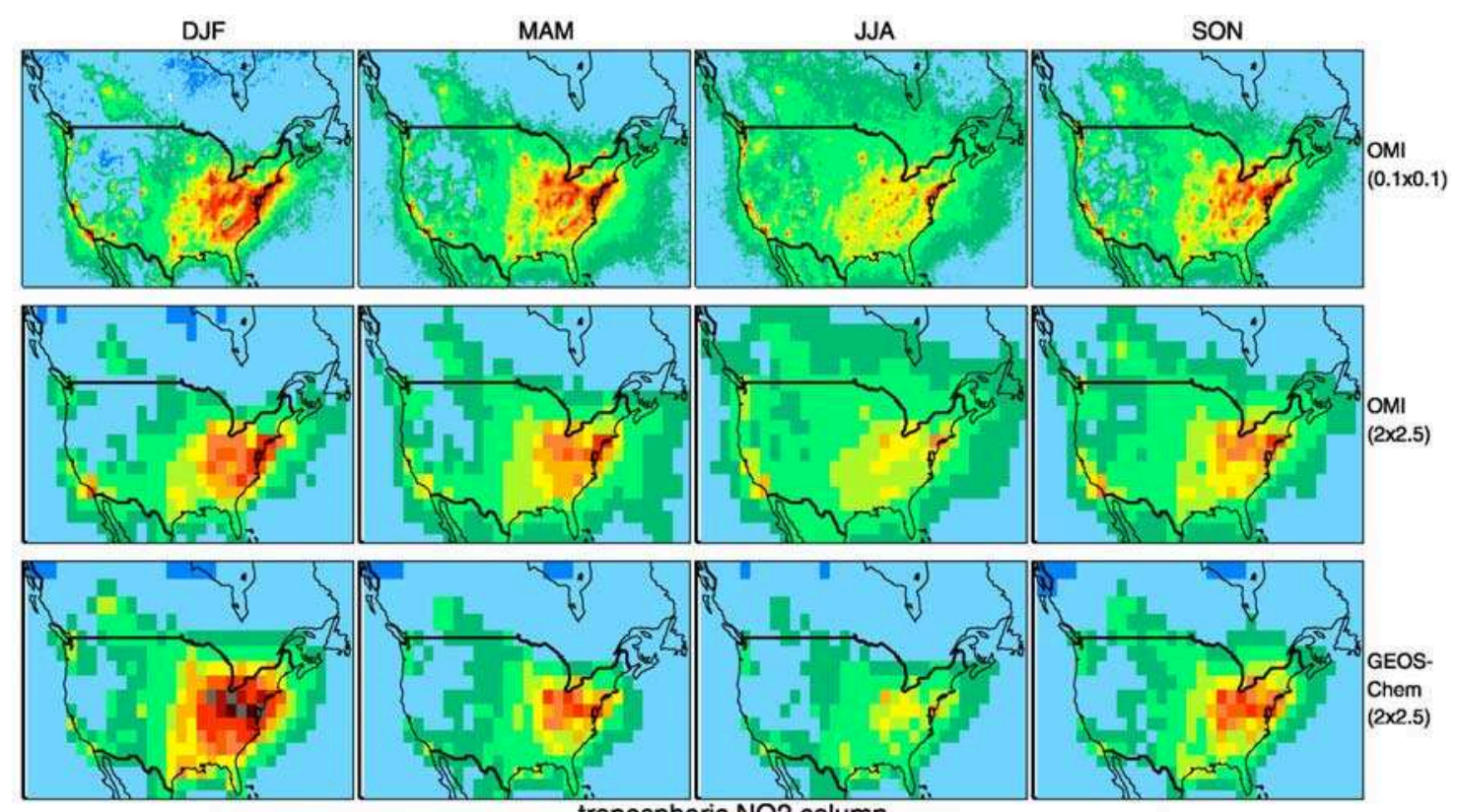

tropospheric NO2 column

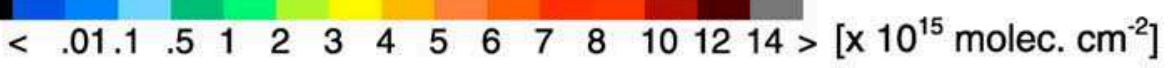

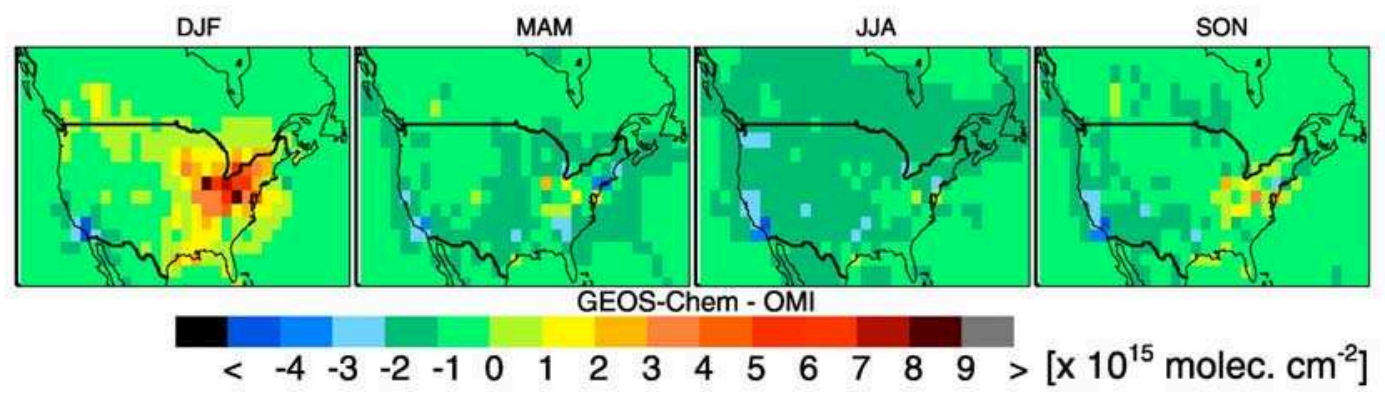

Figure 1. Seasonal mean tropospheric $\mathrm{NO}_{2}$ columns for December-February (DJF), March-May (MAM), June-August (JJA), and September-November (SON) for 2005 from OMI near the intrinsic spatial resolution of OMI at (first row) $0.1^{\circ} \times 0.1^{\circ}$ and (second row) at $2^{\circ} \times 2.5^{\circ}$, and (third row) GEOSChem. (fourth row) The difference between GEOS-Chem and OMI tropospheric $\mathrm{NO}_{2}$ columns.

from $\mathrm{NO}$ and $\mathrm{O}_{3}$ measurements, assuming a photochemical steady state.

\subsection{Interference in $\mathrm{NO}_{2}$ Measurements-Case Studies}

[17] A detailed description of the measurement technique of these commercial analyzers has been given in Fontjin et al. [1970] and U.S. Environmental Protection Agency [1975]. In brief, these instruments operate alternately in $\mathrm{NO}$ and $\mathrm{NO}_{x}$ modes providing the measurements of $\mathrm{NO}$ and $\mathrm{NO}_{x}$, respectively. In $\mathrm{NO}$ mode, the reaction of $\mathrm{NO}$ with ozone produces a characteristic luminescence with an intensity proportional to the concentration of NO. In $\mathrm{NO}_{x}$ mode, $\mathrm{NO}_{2}$ and other $\mathrm{NO}_{z}$ compounds are transformed into $\mathrm{NO}$ over a molybdenum converter heated to approximately $400^{\circ} \mathrm{C}$ and $\mathrm{NO}_{x}$ ( $\mathrm{NO}+$ converted $\mathrm{NO}$ ) is measured by chemiluminescence. The $\mathrm{NO}_{2}$ concentration is derived by subtracting the measurement obtained in the NO mode from that obtained in the $\mathrm{NO}_{x}$ mode. Because the reduction of $\mathrm{NO}_{2}$ to $\mathrm{NO}$ is not specific to $\mathrm{NO}_{2}$ and $\mathrm{NO}_{z}$ species are also reduced to NO, these chemiluminescence analyzers overes- timate ambient $\mathrm{NO}_{2}$ concentration by a variable amount [Winer et al., 1974; U.S. Environmental Protection Agency, 1975; Grosjean and Harrison, 1985; Demerjian, 2000; McClenny et al., 2002; Gerboles et al., 2003; Dunlea et al., 2007; Steinbacher et al., 2007].

\subsubsection{Comparison With DOAS Measurements}

[18] Here we examine the bias in the $\mathrm{NO}_{2}$ measurement network. We compare measurements of $\mathrm{NO}_{2}$ from the standard chemiluminescence analyzer equipped with a molybdenum converter with those from a collocated Differential Optical Absorption Spectroscopy (DOAS) instrument. These measurements are available from the Mexico City Metropolitan Area (MCMA) field campaign [de Foy et al., 2005; Molina et al., 2007] held in April/May of 2003. The chemiluminescence analyzer was calibrated as described by Dunlea et al. [2007]. The detection limit of the research grade DOAS instrument is 4 ppbv.

[19] Figure 2 shows the time series of measurements by the two instruments at La Merced in the downtown area of Mexico City. The two measurements are in good agreement 


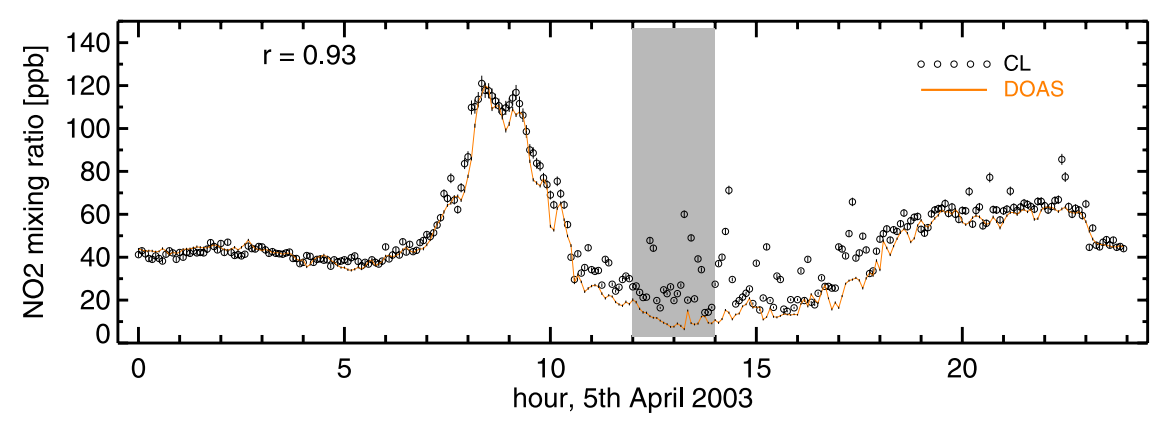

Figure 2. Time series of the $\mathrm{NO}_{2}$ mixing ratio measured by a chemiluminescence monitor (denoted by CL) and a DOAS instrument at La Merced, Mexico City, on 5 April 2003. The bars inside circles and those on the DOAS curve represent the $3 \sigma$ uncertainty in the chemiluminescent and DOAS measurements, respectively. Time of day is for local time. The shaded region highlights the period of OMI overpasses.

before $10 \mathrm{AM}$ and after $6 \mathrm{PM}(\mathrm{r}=0.93, \mathrm{~N}=276)$. A significant difference is observed during afternoon hours. The main cause for the observed discrepancy is the interference in the chemiluminescence measurements [Dunlea et al., 2007], although some difficulties remain when comparing a point measurement with a long path measurement (DOAS) due to spatial incoherence, which is expected to be more of an issue overnight [Dunlea et al., 2006; San Martini et al., 2006]. The main interfering constituents are the oxidation products of $\mathrm{NO}_{x}$ such as $\mathrm{HNO}_{3}$, PAN, and other organic nitrates [Winer et al., 1974; U.S. Environmental Protection Agency, 1975; Fehsenfeld et al., 1987; Demerjian, 2000; Dunlea et al., 2007; Steinbacher et al., 2007].

[20] During the OMI overpass time, when the interference increases as a result of conversion of ambient $\mathrm{NO}_{2}$ into other nitrogen compounds, the DOAS measurements are $51 \%$ lower than that from the chemiluminescence monitor. We caution, however, that the interference evaluated in this example may not be representative of other chemiluminescent analyzers that are used by AQS/NAPS networks because of differences in instrument design and in the concentrations of interfering species. Dunlea et al. [2007] examined other reactive nitrogen species measured during the MCMA-2003 field campaign and concluded that the major species contributing to the observed interference are $\mathrm{HNO}_{3}$, which accounts for $60 \%$ of the bias, and the sum of all alkyl nitrates, which accounts for $10-30 \%$ of the observed interference. They conclude that particulate phase nitrate, PAN, and similar peroxyacyl nitrate compounds do not contribute significantly to the interference at the measurement site in Mexico City.

\subsubsection{Comparison With Photolytic Converter Measurements}

[21] Simultaneous measurements of surface $\mathrm{NO}_{2}$ using the chemiluminescence analyzers equipped with molybdenum and photolytic converters were carried out from January 1995 to August 2001 at Taenikon $\left(47^{\circ} 28^{\prime} \mathrm{N}\right.$, $8^{\circ} 54^{\prime} \mathrm{E}, 539 \mathrm{~m}$ above sea level) located in the eastern part of the Swiss Plateau north of the Alps [Steinbacher et al., 2007]. The rural site Taenikon is influenced only slightly by local traffic. This measurement site is part of the Swiss Air Pollution Monitoring Network (NABEL) jointly operated by EMPA and the Swiss Federal Office for the Environ- ment. In the analyzer equipped with a photolytic converter (CLD $770 \mathrm{AL}$, Ecophysics), $\mathrm{NO}_{2}$ is photolytically converted to NO (PLC 760, Ecophysics). Calibration procedures are summarized by Zellweger et al. [2000] and Steinbacher et al. [2007]; overall uncertainties for $1 \mathrm{~h}$ averages in $\mathrm{NO}_{2}$ by this method are $\pm 10 \%$. The photolytic converter instrument has been shown to be almost interference free for $\mathrm{NO}_{2}$ [Fehsenfeld et al., 1990] with the exception of HONO [Ryerson et al., 2000]. However, levels of HONO are typically much less than $1 \mathrm{ppbv}$ even under heavily polluted conditions [Stutz et al., 2004]. $\mathrm{NO}_{2}$ measurements with molybdenum converter were made using a CLD $700 \mathrm{AL}$ (Ecophysics). The molybdenum converter temperature was at $375^{\circ} \mathrm{C}$. The converter efficiency was determined once a year and was always $>98 \%$. The same standards were used as for the photolytic converter system. $\mathrm{O}_{3}$ was continuously measured using a commercially available instrument based on UV absorption (Monitor Labs 9810). The instrument was regularly compared to a transfer standard (Thermo Environmental Instruments 49C PS) which was traced back to a NIST standard reference photometer.

[22] Our interest here is to quantify the interference in the chemiluminescence molybdenum converter at the OMI overpass time. We average both data over $12: 00 \mathrm{~h}$ to 14:00 h local time. Two complete years (1999 and 2000) are examined for the seasonal variation of $\mathrm{NO}_{z}$ contamination of the molybdenum converter measurements. Table 1 contains a summary of the comparison. $\mathrm{NO}_{2}$ concentrations are strongly correlated $\left(\mathrm{R}^{2}>0.96\right)$.

[23] Figure 3 (top) shows the average $\mathrm{NO}_{2}$ mixing ratio measured by the instruments with photolytic and molybdenum converters. Measurements from both instruments exhibit a distinct seasonal cycle with a summertime minima. $\mathrm{NO}_{2}$ concentrations measured with the molybdenum converter are on average $63 \%$ and $79 \%$ higher in winter/spring and summer/fall, respectively than those measured with the photolytic converter. For April, the mean photolytic converter measurements are $46 \%$ lower than the measurements from the molybdenum converter instrument, suggesting that the relative magnitude of the interference at this rural site (Taenikon) is similar to that of a heavily polluted site (Mexico City). 
Table 1. Summary of $\mathrm{NO}_{2}$ Concentrations at Taenikon for 1999-2000

\begin{tabular}{|c|c|c|c|c|}
\hline \multirow[b]{2}{*}{ Photolytic versus } & \multicolumn{2}{|c|}{ Mean Bias $\pm \sigma[\%]$} & \multicolumn{2}{|c|}{$\mathrm{R}^{2}$} \\
\hline & Winter/Spring & Summer/Fall & Winter/Spring & Summer/Fal \\
\hline Molybdenum & $63.2 \pm 64.9(41.5)^{\mathrm{a}}$ & $78.8 \pm 71.0(62.4)$ & 0.97 & 0.96 \\
\hline Molybdenum cor. & $3.1 \pm 25.1(-0.2)$ & $-1.6 \pm 32.4(-7.4)$ & 0.96 & 0.94 \\
\hline PSS-NO $(a)^{b}$ & $-11.4 \pm 30.3(-12.5)$ & $-6.3 \pm 27.5(-9.8)$ & 0.88 & 0.86 \\
\hline PSS-NO $\mathrm{NO}_{2}(\mathrm{~b})$ & $-6.5 \pm 33.8(-10.5)$ & $6.6 \pm 32.9(0.4)$ & 0.88 & 0.87 \\
\hline
\end{tabular}

${ }^{\mathrm{a}}$ Values in parentheses indicate median bias.

${ }^{b} \mathrm{PSS}-\mathrm{NO}_{2}$ (a) is based on reactions neglecting $\mathrm{HO}_{2}$ and $\mathrm{RO}_{2}$ while PSS-NO $\mathrm{NO}_{2}$ (b) considers the reaction with $\mathrm{HO}_{2}$.

[24] The ratio of the two measurements (photolytic divided by molybdenum) is shown in Figure 3 (bottom). The ratio shows a clear seasonal cycle with summertime minima. Schaub et al. [2006] and Ordóñez et al. [2006] termed similar ratios a "correction factor" and used the monthly values to correct the molybdenum converter measurements for comparison with the GOME $\mathrm{NO}_{2}$ retrievals.

[25] Measurements of PAN at Taenikon showed a diurnal cycle with highest values in the afternoon and a seasonal cycle, consistent with the interference ratio of the two $\mathrm{NO}_{2}$ measurements shown in Figure 3. Therefore Steinbacher et al. [2007] consider PAN to be a major contributor (30$50 \%$ ) to the observed interference in the molybdenum converter measurements, followed by interference due to nitric acid. The case studies at the two sites with different field situations (urban Mexico City and rural Taenikon) indicate that the percentage contributions of the interfering species to the molybdenum converter measurements depend on their relative abundance.

\subsection{Correction for Interference}

[26] The two case studies presented in section 3.1 suggest that in order to evaluate surface $\mathrm{NO}_{2}$ inferred from OMI with the AQS/NAPS networks it is necessary to correct for interference in the molybdenum converter measurements. The correction requires information on the concentration of various interfering species which is not available from the

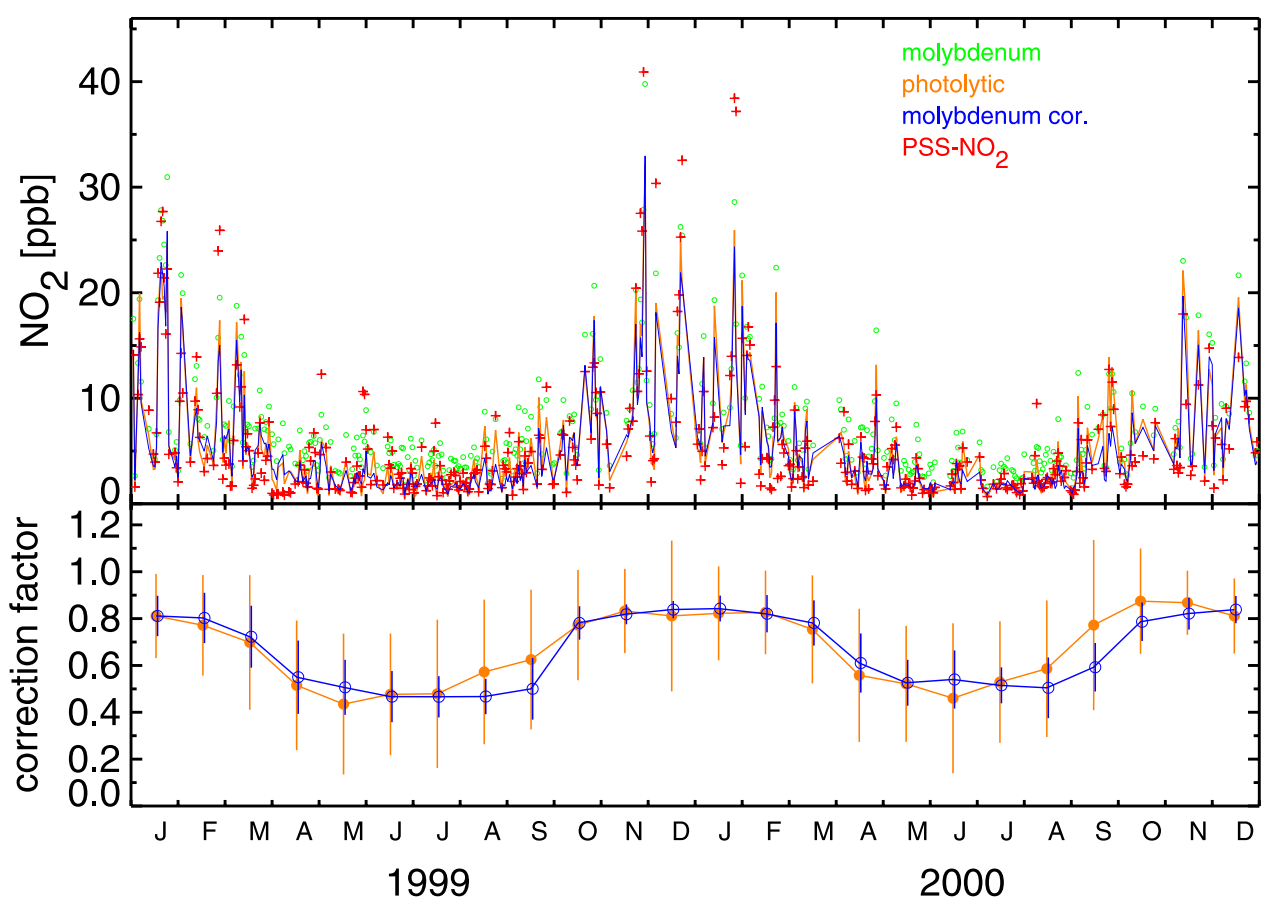

Figure 3. (top) This contains daily 2-hour average (12:00 to 14:00 local time) $\mathrm{NO}_{2}$ mixing ratio at Taenikon, Switzerland, for the year 1999 and 2000. The open circles (in green) represent the measurements using the chemiluminescence analyzer equipped with the molybdenum converter. The orange line represents the measurements using the analyzer equipped with the photolytic converter. The blue line shows the measurements with the molybdenum converter after applying the correction factor determined from the GEOS-Chem model, as discussed in section 3.2. The red plus symbols are the PSS- $\mathrm{NO}_{2}$ estimated from simultaneous measurements of $\mathrm{O}_{3}$ and $\mathrm{NO}$, as described in section 3.3. (bottom) Monthly means of the correction factors. The orange line represents the ratio of measurements using the analyzer equipped with the photolytic and molybdenum converters. The blue line shows the correction factor calculated using equation (1). The bars represent the $2 \sigma$ variability of the average. 


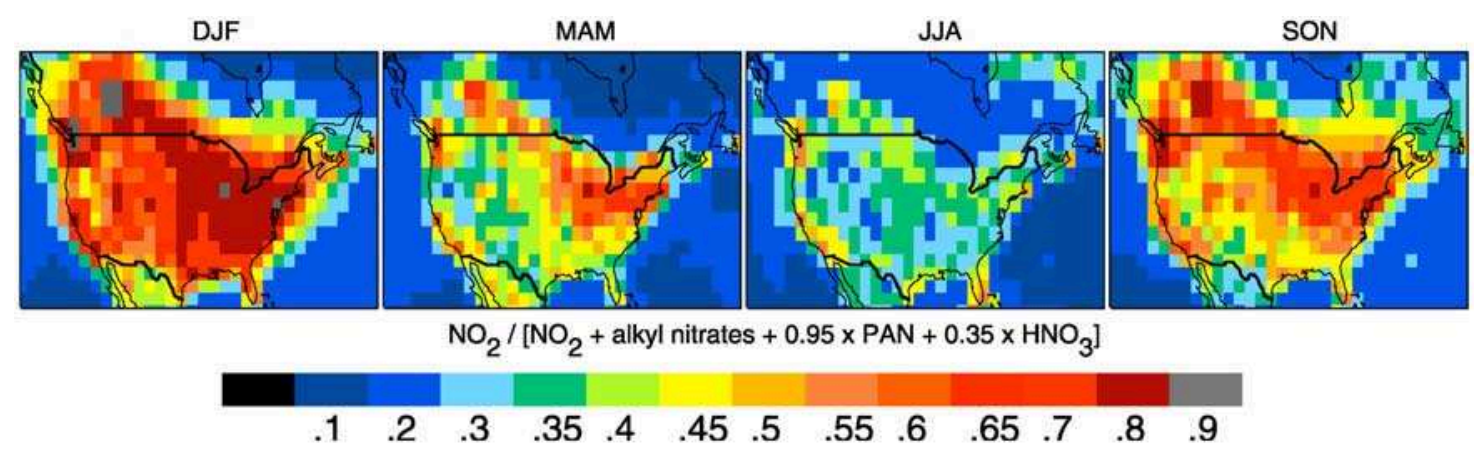

Figure 4. Seasonally averaged correction factors for interference in ground-level $\mathrm{NO}_{2}$ measurements using molybdenum converters as estimated from a GEOS-Chem simulation (see equation (1)) for the year 2005 .

AQS/NAPS monitoring sites. Our main aim here is to devise a method to correct for interference in the $\mathrm{NO}_{2}$ measurements by the molybdenum converter instruments.

[27] The percentage contributions of the interfering species at a site depend strongly on the concentration of $\mathrm{NO}_{z}$ species, the distance of emission sources, and on meteorological conditions [Gerboles et al., 2003]. A further complication is that $\mathrm{HNO}_{3}$ can deposit to and evaporate from surfaces in the inlet manifold, which is unique to each monitor [Neuman et al., 1999; D. Parrish, private communication, 2007; Dunlea et al., 2007].

[28] Laboratory experiments have shown that the commercial chemiluminescent molybdenum converter analyzer responds nearly quantitatively to $\mathrm{NO}$, ethyl nitrate, and PAN. Over a wide range of concentrations ( 0 to $>350 \mathrm{ppbv})$, the conversion efficiencies for ethyl nitrate and PAN are $\sim 100 \%$ and $92 \%$ respectively [Winer et al., 1974]. Grosjean and Harrison [1985] found a similar conversion efficiency ( $\geq 98 \%$ ) for $\mathrm{HNO}_{3}$, PAN, n-propyl nitrate, and n-butyl nitrate. Field observations show that the contribution of other species such as particulate nitrate, gas phase olefins, and ammonia to the interference is negligible in at least one instance and is likely to be insignificant everywhere [Dunlea et al., 2007]. We take 95\% (average value from the two experiments) for the conversion efficiency of PAN and $100 \%$ for the sum of all alkyl nitrates ( $\Sigma A N)$. Quantitative translation of $\mathrm{HNO}_{3}$ inlet loss to conversion efficiency is difficult to estimate. We find that a conversion efficiency of $35 \%$ for $\mathrm{HNO}_{3}$ best resolves the discrepancies at the OMI overpass time between the molybdenum and photolytic converter measurements. This low efficiency is supported by previous laboratory studies of the loss of $\mathrm{HNO}_{3}$ on stainless steel inlets [Neuman et al., 1999]. Implications to the overall comparison are discussed in section 5. We use the following correction factor $(\mathrm{CF})$ to estimate corrected $\mathrm{NO}_{2}$ concentrations:

$$
\mathrm{CF}=\frac{\mathrm{NO}_{2}}{\mathrm{NO}_{2}+\Sigma \mathrm{AN}+(0.95 \mathrm{PAN})+\left(0.35 \mathrm{HNO}_{3}\right)} .
$$

[29] As a first test, we apply the correction factors to the molybdenum converter measurements at Taenikon. We perform a simulation with the GEOS-Chem model for the years 1999 and 2000 following an 8-month spin up. The 2-hour (12:00 to 14:00 local time) average correction factors computed from equation (1) are applied to correct for interference in the molybdenum converter measurements. The blue line in Figure 3 (top) shows the corrected measurements. The corrected molybdenum converter measurements are well correlated with the photolytic converter measurements $\left(\mathrm{R}^{2}=0.95, \mathrm{~N}=382\right)$. Excellent agreement (mean bias $<4 \%$ ) with the photolytic converter measurements lends support to our approach. Figure 3 (bottom) shows that the GEOS-Chem based correction factors well reproduce the ratio of the photolytic and molybdenum converter measurements for most of the time period.

[30] We extend equation (1) to all sites in North America. Figure 4 shows the seasonal means of the correction factors determined with concentrations of the interfering species predicted by GEOS-Chem at the OMI overpass time. A strong seasonal pattern is evident, with the correction factors being closer to unity during winter due to the longer $\mathrm{NO}_{x}$ lifetime. The correction factor tends to be closer to unity over polluted regions (e.g., California and northeastern United States) where $\mathrm{NO}_{x}$ is a large fraction of total reactive nitrogen $\left(\mathrm{NO}_{y}\right)$. A larger correction in summer occurs when $\mathrm{HNO}_{3}, \mathrm{PAN}$, and other organic nitrates make large contributions to $\mathrm{NO}_{y}$.

\subsection{Estimation of $\mathrm{NO}_{2}$ Using Photochemical Steady-State Calculation}

[31] Here we explore an alternative approach to estimate ground-level $\mathrm{NO}_{2}$ by a photochemical steady-state calculation. The approach exploits the fact that oxidation of $\mathrm{NO}$ to $\mathrm{NO}_{2}$ and photodissociation of $\mathrm{NO}_{2}$ to $\mathrm{NO}$ by solar UV radiation tends to establish the photochemical steady state within a few minutes:

$$
\left[\mathrm{NO}_{2}\right]^{\mathrm{PSS}}=[\mathrm{NO}] \times \frac{\mathrm{k}_{1}\left[\mathrm{O}_{3}\right]+\mathrm{k}_{2}\left[\mathrm{HO}_{2}\right]+\mathrm{k}_{3}\left[\mathrm{RO}_{2}\right]}{\mathrm{J}_{\mathrm{NO}_{2}}},
$$

where $\mathrm{J}_{\mathrm{NO} 2}$ is the photolysis rate of $\mathrm{NO}_{2}$ and $\mathrm{k}_{1}, \mathrm{k}_{2}$, and $\mathrm{k}_{3}$ are the reaction rate constants. Accurate simultaneous measurements of $\mathrm{NO}, \mathrm{O}_{3}, \mathrm{HO}_{2}, \mathrm{RO}_{2}$, and $\mathrm{J}_{\mathrm{NO} 2}$ are needed to estimate $\mathrm{NO}_{2}$ concentrations. A major obstacle to the approach of estimating $\mathrm{NO}_{2}$ by PSS is that the $\mathrm{NO}_{\mathrm{x}}$ monitoring sites lack measurements of $\mathrm{J}_{\mathrm{NO} 2}$ and peroxy radicals.

[32] We first assess the feasibility of estimating $\mathrm{NO}_{2}$ concentrations by PSS at Taenikon. We consider $\mathrm{O}_{3}$ and 
NO concentrations measured simultaneously with $\mathrm{NO}_{2}$ on clear sky conditions at the OMI overpass time. Photolysis rates of $\mathrm{NO}_{2}$ are calculated for the same time interval under clear sky conditions using the Fast-J scheme [Wild et al., 2000; Barnard et al., 2004]. The reactions with $\mathrm{HO}_{2}$ and $\mathrm{RO}_{2}$ are neglected initially due to the lack of observations but are expected to alter the ratio of $\mathrm{NO}_{2}$ to $\mathrm{NO}$ by $<10 \%$.

[33] Figure 3 and Table 1 contain the PSS- $\mathrm{NO}_{2} . \mathrm{We}$ exclude those observations that correspond to unrealistically high PSS- $\mathrm{NO}_{2}$ values exceeding the molybdenum converter measurements. This removes $15 \%$ of the data in winter/ spring and $6.9 \%$ in summer/fall. The estimated $\mathrm{NO}_{2}$ concentrations are well correlated with the photolytic converter measurements $\left(\mathrm{R}^{2}=0.86, \mathrm{~N}=382\right)$ and exhibit similar seasonal variation. However, the PSS- $\mathrm{NO}_{2}$ underestimates the photolytic converter measurements by $11 \%$ in winter/ spring and $6.3 \%$ in summer/fall. Including simulated $\mathrm{HO}_{2}$ concentrations in the PSS calculations improves the agreement by $4.9 \%$ in winter/spring, but overestimates by $6.6 \%$ the photolytic converter measurements in summer/fall. Possible explanations for the remaining discrepancy include: (1) neglect of $\mathrm{RO}_{2}$ for the $\mathrm{PSS}-\mathrm{NO}_{2}$ calculations (2) errors in calculated $\mathrm{J}_{\mathrm{NO} 2}$ (3) local sources and sinks near a measurement site that result in nonsteady state conditions [Mannschreck et al., 2004], (4) conversion of $\mathrm{NO}$ to $\mathrm{NO}_{2}$ by other reactants [e.g., Volz-Thomas et al., 2003; Mannschreck et al., 2004; Matsumoto et al., 2006], (5) uncertainties in $\mathrm{k}_{1}$ [Mannschreck et al., 2004], and (6) measurement errors in $\mathrm{NO}$ and $\mathrm{O}_{3}$. It appears that the errors in the corrected molybdenum converter measurements are lower than those in the PSS calculation.

\section{Determination of Ground-Level $\mathrm{NO}_{2}$ Concentrations From OMI}

[34] We go on to infer ground-level $\mathrm{NO}_{2}$ concentrations from OMI for comparison with the in situ measurements. Simulated annual mean $\mathrm{NO}_{2}$ columns over North America exhibits significant spatial correlation $\left(\mathrm{R}^{2}=0.96, \mathrm{~N}=652\right)$ with simulated surface $\mathrm{NO}_{2}$ concentrations. Aircraft measurements reveal that $\mathrm{NO}_{2}$ within the boundary layer typically makes a dominant contribution to tropospheric $\mathrm{NO}_{2}$ columns over land [Martin et al., 2004a, 2006; Bucsela et al., 2008; Boersma et al., 2008b], but that relationship varies in space and time. We use the GEOS-Chem local $\mathrm{NO}_{2}$ profile to capture that variation and estimate groundlevel $\mathrm{NO}_{2}$ concentrations from $\mathrm{OMI}$ :

$$
\mathrm{S}_{\mathrm{O}}=\frac{\mathrm{S}_{\mathrm{G}}}{\Omega_{\mathrm{G}}} \times \Omega_{\mathrm{O}}
$$

[35] Here $\mathrm{S}$ represents the surface level mixing ratio and $\Omega$ represents the tropospheric $\mathrm{NO}_{2}$ column. Subscript "O" denotes OMI and "G" denotes GEOS-Chem. The OMIderived surface $\mathrm{NO}_{2}$ represents the mixing ratio at the lowest vertical layer $(100 \mathrm{~m})$ of the model.

[36] The relative vertical profile of $\mathrm{NO}_{2}$ calculated with the GEOS-Chem model is generally consistent with in situ aircraft measurements [Martin et al., 2004a, 2006; Hudman et al., 2007]. Spatial variation in the OMI observations within the $2^{\circ} \times 2.5^{\circ}$ resolution of the GEOS-Chem simu- lation reflects spatial variation of $\mathrm{NO}_{2}$ concentrations in the boundary layer.

[37] We develop a scheme to combine both information sources to infer $\mathrm{NO}_{2}$ vertical profiles at the OMI resolution. Let $\nu$ represents the ratio of the local OMI $\mathrm{NO}_{2}$ column to the mean OMI field over a GEOS-Chem grid $\bar{\Omega}_{\mathrm{O}}$. The simulated free tropospheric $\mathrm{NO}_{2}$ column $\Omega_{\mathrm{G}}^{\mathrm{F}}$ is taken as horizontally invariant over a GEOS-Chem grid, reflecting the longer $\mathrm{NO}_{x}$ lifetime in the free troposphere. The groundlevel $\mathrm{NO}_{2}$ concentrations $\left(\mathrm{S}_{\mathrm{O}}^{\prime}\right)$ is thus given by

$$
\mathrm{S}_{\mathrm{O}}^{\prime}=\frac{\nu \mathrm{S}_{\mathrm{G}}}{\nu \Omega_{\mathrm{G}}-(\nu-1) \Omega_{\mathrm{G}}^{\mathrm{F}}} \times \Omega_{\mathrm{O}}
$$

equation (4) collapses to equation (3) when $v$ equals unity. $\mathrm{NO}_{2}$ concentrations calculated with equation (4) differ from those calculated with equation (3) by up to $\pm 12 \%$ in urban areas and $\pm 35 \%$ in rural areas. Local sources are better resolved.

[38] Figure 5 (first row) shows the OMI-derived surface $\mathrm{NO}_{2}$ concentrations calculated with equation (4). A clear seasonal variation is observed with larger values during winter that reflects shallow mixing depths and the longer $\mathrm{NO}_{x}$ lifetime [Munger et al., 1998]. Enhanced concentrations of up to $10 \mathrm{ppbv}$ are evident in urban areas, in contrast with concentrations of less than $0.1 \mathrm{ppbv}$ in rural areas.

[39] We use the in situ measurements to examine how the afternoon observations relate to 24-hour concentrations. Figure 6 shows the annual mean diurnal variation in the measurements from the EPA/AQS networks. Higher concentrations occur at night when photolysis ceases and the mixed layer shrinks, and in early morning at suburban and urban sites when traffic increases. Annual 24-hr average concentrations are $36 \%$ higher than at the OMI overpass time. The diurnal variation could be even larger considering diurnal variation in the $\mathrm{NO}_{2}$ interference. The diurnal variation is weakest in winter reflecting the longer $\mathrm{NO}_{x}$ lifetime.

\section{Comparison of In Situ and OMI-Derived Surface $\mathrm{NO}_{2}$ Concentrations}

[40] We compare the OMI-derived surface $\mathrm{NO}_{2}$ with the ground-based measurements throughout the United States and Canada. Stations must be within $200 \mathrm{~m}$ altitude of OMI grid and consist of at least 30 coincident measurements with OMI over the year 2005. The maximum allowed collocation radius (distance between center of OMI grid and station) is $10 \mathrm{~km}$. The nearest OMI grid is selected for a given day. These criteria retain 296 stations, which include 266 from the United States and 30 from Canada in both polluted and remote regions. We average the hourly in situ measurements over a 2-hour period (12:00 to 14:00 local time) to correspond with the OMI measurements over North America.

[41] Figure 5 (second row) shows the OMI observations at in situ sites; most sites are in polluted regions. Figure 5 (third and fifth rows) display, respectively, the corrected and uncorrected seasonal average ground-level $\mathrm{NO}_{2}$ mixing ratios. The uncorrected $\mathrm{NO}_{2}$ mixing ratios are up to a factor of three higher than the corrected measurements in summer. Both OMI and the corrected in situ measurements exhibit a broadly similar seasonal variation $(\mathrm{r}=0.76, \mathrm{~N}=1191)$. This 


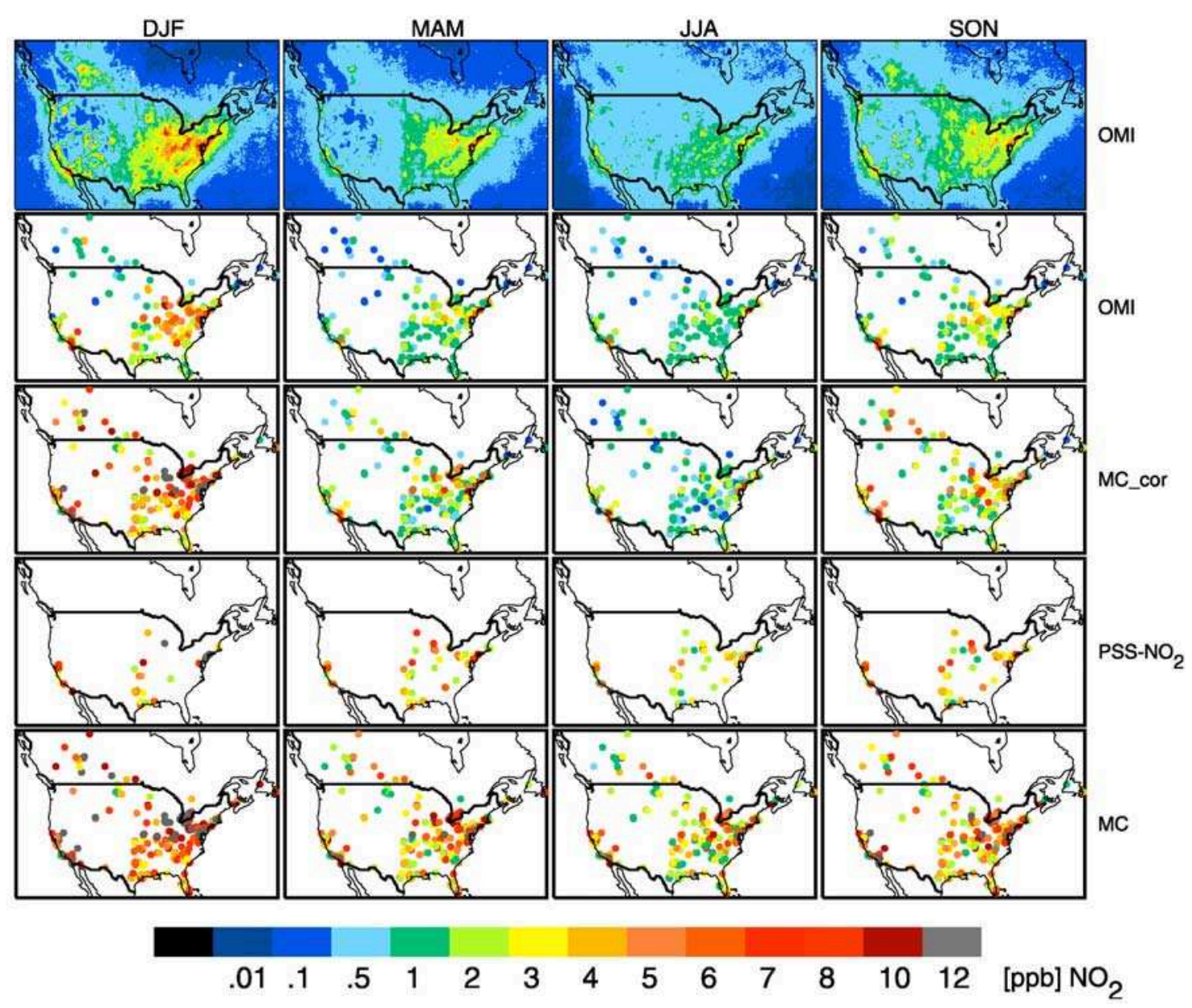

Figure 5. Seasonal average of surface $\mathrm{NO}_{2}$ mixing ratios for the year 2005. (first row) A seasonal map of OMI-derived surface NO2 over North America. (second row) The collocated OMI-derived surface $\mathrm{NO}_{2}$ at the NAPS/AQS sites. (third row) The corrected molybdenum converter (MC) measurements, denoted by MC_cor, as discussed in section 3.2. (fourth row) PSS-NO ${ }_{2}$, as discussed in section 3.3. Only a limited number of sites fulfilling the selection criteria for the PSS- $\mathrm{NO}_{2}$ calculations are evident. (fifth row) The in situ molybdenum converter measurements obtained from the NAPS/AQS network, denoted by MC.

relationship is even more consistent than found by Liu et al. [2004] and van Donkelaar et al. [2006] between satellitederived and in situ $\mathrm{PM}_{2.5}$ measurements. However, the OMI-derived surface $\mathrm{NO}_{2}$ mixing ratios generally are lower than the corrected in situ measurements, especially in winter, as examined further below. Larger differences between the corrected in situ and OMI-derived surface $\mathrm{NO}_{2}$ concentrations in western North America likely reflect a combination of enhanced spatial variation in mountainous regions and preferential placement of monitors in polluted locations. OMI-derived surface $\mathrm{NO}_{2}$ represents mean concentrations over several hundred square kilometers.

[42] We also compare the OMI-derived surface $\mathrm{NO}_{2}$ with the PSS $-\mathrm{NO}_{2}$ for selected sites in North America. The photolysis rates of $\mathrm{NO}_{2}\left(\mathrm{~J}_{\mathrm{NO} 2}\right)$ were calculated for clear sky conditions using the Fast-J scheme. The temperature data required to estimate the reaction rates $\left(\mathrm{k}_{1}\right)$ were obtained from the NASA GMAO. Reactions with $\mathrm{HO}_{2}$ and $\mathrm{RO}_{2}$ were neglected due to absence of measurements. This comparison is limited only to those sites which monitor all three trace species $\left(\mathrm{NO}, \mathrm{NO}_{2}\right.$ and $\left.\mathrm{O}_{3}\right)$. Not all $\mathrm{NO}_{2}$ monitoring sites monitor ground-level ozone. The ozone data are available only for 5 or 6 months (high ozone season) of the year in many states in the United States. Many stations were excluded from this comparison if the PSS-NO $\mathrm{N}_{2}$ resulted in unrealistically high values (>molybdenum converter measurements) for numerous days $(>30 \%$ of the observations for a given station).

[43] Figure 5 (fourth row) shows the seasonal average of PSS-NO ${ }_{2}$. Values range from 2-14 ppbv with a tendency of being lower in summer and higher in winter. The paucity of sites, especially in winter, reflects the lack of ozone measurements.

[44] Figure 7 shows the correlation coefficients between the in situ and OMI-derived surface $\mathrm{NO}_{2}$. Figure 7 (left) shows the correlation coefficient with the corrected molybdenum converter measurements. The OMI-derived surface $\mathrm{NO}_{2}$ concentrations are significantly correlated with the in situ measurements, with mean correlation coefficients of 0.49 and a maximum value of 0.86 . Ordónez et al. [2006] 


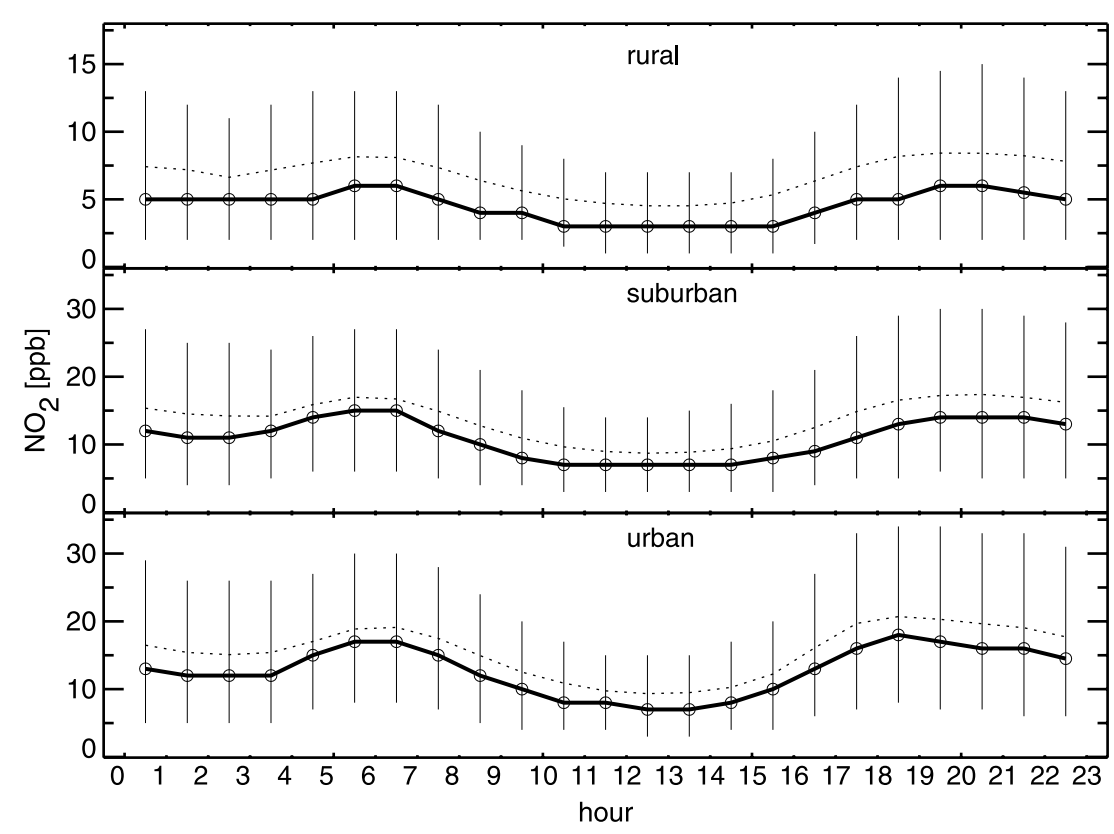

Figure 6. Diurnal variability in a measured 1-hour average $\mathrm{NO}_{2}$ mixing ratios in rural (48), suburban (57), and urban (52) EPA/AQS sites. Values shown are annual averages for 2005. The thick black line with circles represents median values and the bars extend from 17 th to 83 rd percentile range. The dotted line represents mean values.

reported a similar correlation of 0.78 between the GOME tropospheric $\mathrm{NO}_{2}$ column and surface $\mathrm{NO}_{2}$ mixing ratios measured in northern Italy. The correlation tends to be stronger in polluted areas where boundary layer $\mathrm{NO}_{2}$ comprises a large fraction of tropospheric $\mathrm{NO}_{2}$ column. However, no significant regional difference (eastern versus western United States) in the correlation coefficient is evident as reported by van Donkelaar et al. [2006] in the ground-level $\mathrm{PM}_{2.5}$ derived from satellite instruments. Figure 7 (right) shows a similar correlation with the PSS- $\mathrm{NO}_{2}$ estimates at the few available sites.

[45] Figure 8 shows ground-level $\mathrm{NO}_{2}$ concentrations derived from the OMI tropospheric $\mathrm{NO}_{2}$ columns and those measured by chemiluminescence analyzers at five stations with different levels of $\mathrm{NO}_{2}$ for the year 2005. The correction of the in situ measurements results in significantly better agreement with OMI-derived surface $\mathrm{NO}_{2}$. The OMI-derived surface $\mathrm{NO}_{2}$ concentrations capture small-scale features of the in situ measurements. The occasional large discrepancies may reflect local and transient processes.

[46] Figure 8 also shows the PSS- $\mathrm{NO}_{2}$ for the selected five stations. Based on the comparison with photolytic converter measurements at Taenikon the $\mathrm{PSS}-\mathrm{NO}_{2}$ is expected to underestimate true $\mathrm{NO}_{2}$, especially in winter/ spring. Occasional large values exceeding the molybdenum converter measurements are evident. The $\mathrm{NO}_{2}$ concentrations estimated from this approach are generally consistent with the corrected in situ measurements and the OMIderived surface $\mathrm{NO}_{2}$ for North American sites.

[47] The AQS/NAPS $\mathrm{NO}_{2}$ monitoring sites are classified as urban, suburban, and rural. We determine the ratio of the OMI-derived surface $\mathrm{NO}_{2}$ and the corrected in situ measurements for each land use type. These classifications do not provide information on local sources, population density, or other characteristics that might affect monitored concentrations. We exclude all stations in which more than $30 \%$ of PSS- $\mathrm{NO}_{2}$ data exceeded the uncorrected molybdenum converter measurements.

[48] Figure 9 shows the seasonal average ratio of the OMI-derived surface $\mathrm{NO}_{2}$ and the corrected in situ measurements for the remaining sites in eastern North America. Too few sites $(<=5)$ remain for meaningful interpretation in western North America. The annual mean bias (defined by $\left.\frac{\text { OMI-chemiluminescence }}{\text { chemiluminescence }}\right)$ is $-9 \%$ at rural sites, $-23 \%$ at suburban sites, and $-29 \%$ at urban sites. Comparison of the OMI-derived surface $\mathrm{NO}_{2}$ with the PSS-NO $\mathrm{NO}_{2}$ yields similar quantity. The bias reported here is consistent with the underestimate in OMI tropospheric $\mathrm{NO}_{2}$ columns by $15-30 \%$ versus independent column measurements as inferred by Celarier et al. [2008], Bucsela et al. [2008],

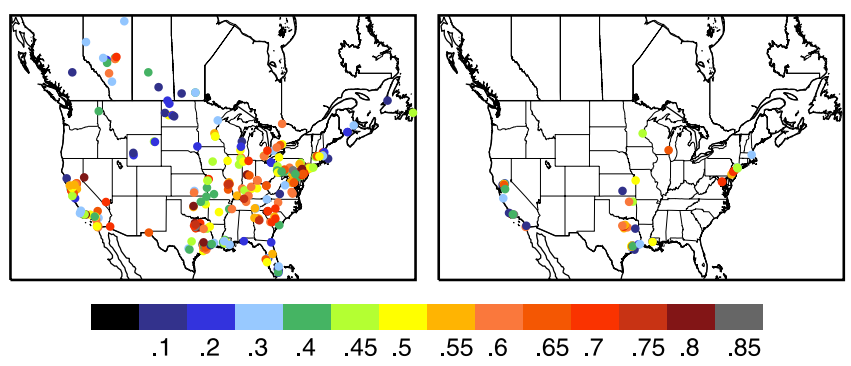

Figure 7. Correlation coefficient (left) between daily, corrected in situ measurements and coincident OMI-derived surface $\mathrm{NO}_{2}$ and (right) between $\mathrm{PSS}-\mathrm{NO}_{2}$ and OMIderived surface $\mathrm{NO}_{2}$ for the year 2005. The correlation coefficient between PSS- $\mathrm{NO}_{2}$ and OMI-derived surface $\mathrm{NO}_{2}$ were calculated only for the selected sites, as discussed in section 5 . 

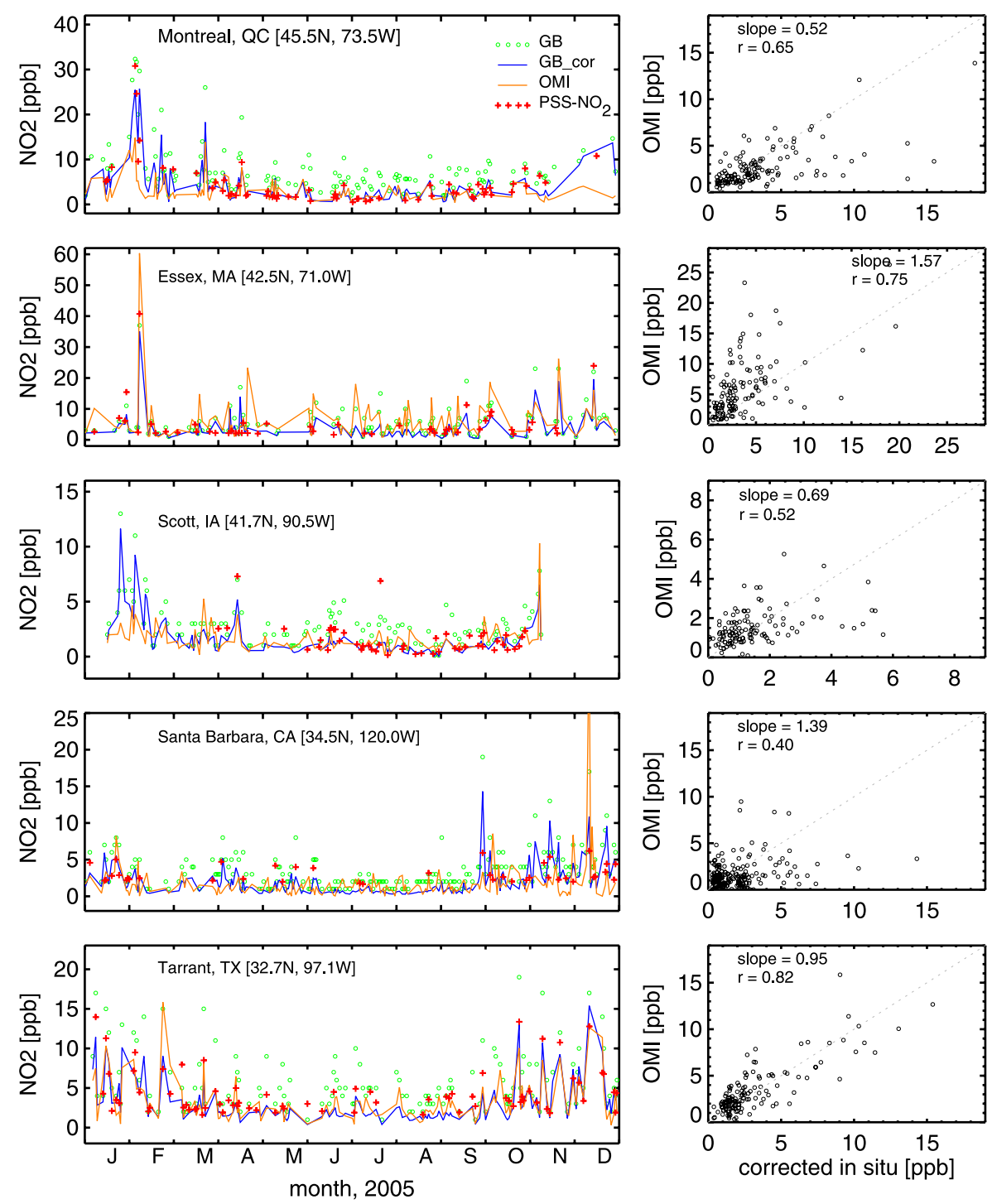

Figure 8. (left) Time series of mean surface $\mathrm{NO}_{2}$ mixing ratios between 12:00 and 14:00 local time for Montreal (QC), Essex (MA), Scott (IA), Santa Barbara (CA), and Terrant (TX). The data obtained from chemiluminescence analyzers and OMI are shown in green circles and orange line, respectively. The blue line shows the corrected in situ measurements. The estimated $\mathrm{NO}_{2}$ values by PSS are represented by red symbols. (right) Scatter plots of the OMI-derived surface $\mathrm{NO}_{2}$ and the corrected ground-based measurements. The regression analysis parameters are given in the legend. The slope was calculated with reduced major-axis linear regression [Hirsch and Gilroy, 1984].

and Wenig et al. [2008]. The preferential placement of surface measurement sites near sources [Demerjian, 2000] also may contribute to the bias.

[49] However, the ratio of the OMI-derived surface $\mathrm{NO}_{2}$ and the corrected in situ measurements exhibits a consistent seasonal variation for all land use types with higher values in summer months. The seasonal variation is more pronounced for rural sites where the mean bias is $11 \%$ for summer/fall and $-27 \%$ for winter/spring. For suburban and urban sites, the mean differences are $-18 \%$ and $-17 \%$, respectively for summer/fall and $-27 \%$ and $-36 \%$, respectively for winter/spring. Comparison of the OMI-derived surface $\mathrm{NO}_{2}$ with the PSS- $\mathrm{NO}_{2}$ yields similar results. In general, the mean bias of the OMI-derived surface $\mathrm{NO}_{2}$ with the PSS-NO $\mathrm{N}_{2}$ is smaller for winter/spring when the PSS$\mathrm{NO}_{2}$ underpredicts ground level $\mathrm{NO}_{2}$ concentrations.

[50] Possible explanations for the seasonal discrepancy between the in situ measurements and OMI include errors in the in situ $\mathrm{NO}_{2}$ concentrations, in the GEOS-Chem $\mathrm{NO}_{2}$ profile, and in the OMI retrieval. The similar discrepancy of OMI-derived surface $\mathrm{NO}_{2}$ versus both the corrected molybdenum converter measurements and the PSS-NO $\mathrm{NO}_{2}$ suggests errors in the in situ based estimates are an insufficient explanation. The seasonal bias cannot be eliminated by assuming different values for $\mathrm{HNO}_{3}$ interference. The bias is largest in winter when the correction factor is smallest, and we have the most confidence in the in situ measurements due to the high $\mathrm{NO}_{2} / \mathrm{NO}_{z}$ ratio. Seasonal errors in the GEOS-Chem $\mathrm{NO}_{2}$ profile cannot be ruled out, but are 


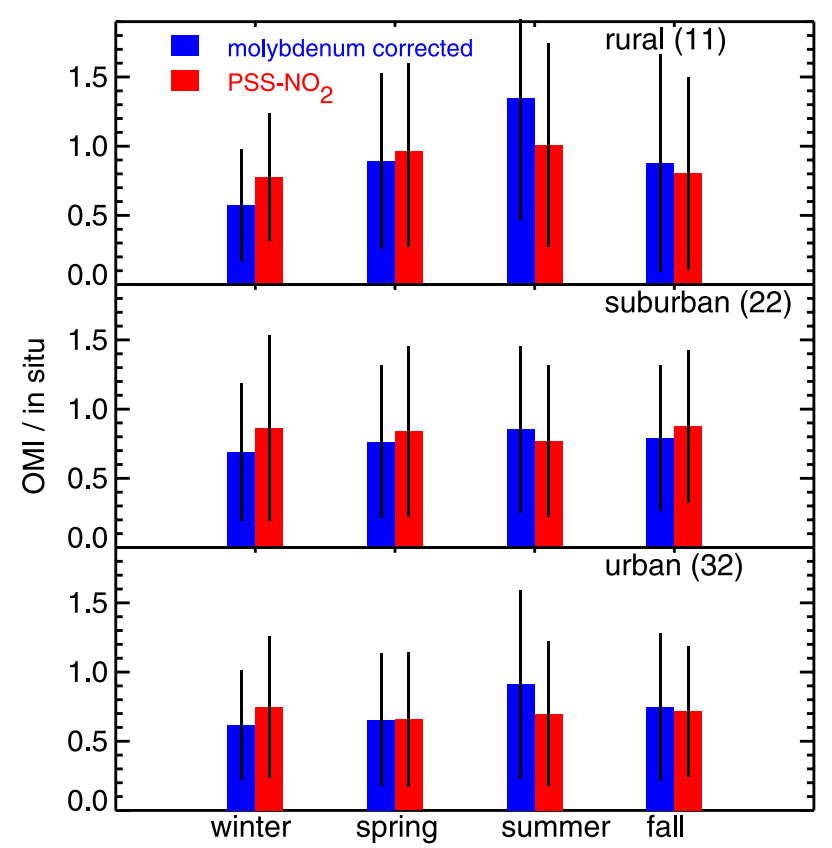

Figure 9. Seasonal mean ratio of OMI-derived surface $\mathrm{NO}_{2}$ concentrations with the corrected in situ measurements (blue bars) and with the PSS- $\mathrm{NO}_{2}$ data (red bars) in eastern North America. The vertical lines are the standard deviation of the seasonal average. Here, the AQS/NAPS $\mathrm{NO}_{2}$ monitoring surface sites are classified by land use types as rural, suburban, and urban. The number of stations included is in parentheses.

unlikely to fully explain the discrepancy given previous comparisons with aircraft measurements [Martin et al., 2004a, 2006; Hudman et al., 2007; Singh et al., 2007; Celarier et al., 2008; Bucsela et al., 2008]. The OMI-in situ bias in eastern North America is comparable in magnitude and sign to the bias between OMI and GEOS-Chem $\mathrm{NO}_{2}$ columns (Figure 1). A likely contributor to the seasonal bias is the use of annual mean $\mathrm{NO}_{2}$ profiles in the OMI air mass factor calculation. Seasonal variation in mixed-layer depths would yield an underestimate in retrieved $\mathrm{NO}_{2}$ columns in winter versus in summer. The larger seasonal bias at rural sites suggests a contribution from the removal of stratospheric $\mathrm{NO}_{2}$ which has a larger relative effect where tropospheric $\mathrm{NO}_{2}$ columns are lower. Seasonal variation in surface reflectivity could also play a role.

\section{Conclusion}

[51] We inferred ground-level concentrations of nitrogen dioxide $\left(\mathrm{NO}_{2}\right)$ for 2005 from Ozone Monitoring Instrument (OMI) tropospheric $\mathrm{NO}_{2}$ column measurements by applying coincident $\mathrm{NO}_{2}$ profiles from a global chemical transport model (GEOS-Chem). Spatial variation in OMI observations was exploited to estimate the local $\mathrm{NO}_{2}$ profile. The OMI-derived surface $\mathrm{NO}_{2}$ was compared to the in situ measurements throughout the United States and Canada from the Air Quality System (AQS) and National Air Pollution Surveillance (NAPS) networks.

[52] Seasonal mean OMI-derived surface $\mathrm{NO}_{2}$ concentrations vary by more than 2 orders of magnitude $(<0.1-$
$>10$ ppbv) over North America. Larger values in winter reflect the longer $\mathrm{NO}_{x}$ lifetime and more shallow mixing depths than in summer. The diurnal variation in situ measurements indicates that annual mean 24-hour average concentrations are $36 \%$ higher than those at the OMI overpass time of $\sim 13: 00$ over North America.

[53] We developed a validation data set from groundbased measurements. Surface $\mathrm{NO}_{2}$ concentrations were estimated by photochemical steady-state (PSS) calculations from observed $\mathrm{NO}, \mathrm{O}_{3}$, and calculated photolysis frequencies for clear-sky conditions. In-situ $\mathrm{NO}_{2}$ measurements from commercial chemiluminescence analyzers equipped with a molybdenum converter are known to have significant interferences from reactive oxidized nitrogen species $\left(\mathrm{NO}_{z}\right)$. We examined the interference using simultaneous measurements of $\mathrm{NO}_{z}$ species and $\mathrm{NO}_{2}$ from both a chemiluminescent $\mathrm{NO}_{2}$ analyzer and a DOAS instrument during the Mexico City Metropolitan Area (MCMA) field campaign, as well as measurements from chemiluminescent molybdenum and photolytic converters at Taenikon, Switzerland. The interference most strongly depends on ambient concentrations of $\mathrm{HNO}_{3}, \mathrm{PAN}$, and alkyl nitrates, but varies with season and location. We developed an algorithm to correct the interference with additional guidance from laboratory studies on the conversion efficiency of molybdenum converters for these interfering species. We estimated the magnitude of the interference using coincident simulated values of $\mathrm{HNO}_{3}, \mathrm{PAN}$, and alkyl nitrates from GEOS-Chem, and applied the correction factors to the in situ measurements throughout the United States and Canada. Evaluation of both the PSS-NO $\mathrm{N}_{2}$ and the corrected in situ measurements with the photolytic converter measurements suggests higher errors in the PSS- $\mathrm{NO}_{2}$ estimate.

[54] We use the ground-based $\mathrm{NO}_{2}$ concentrations to validate our surface $\mathrm{NO}_{2}$ estimate and indirectly validate the $\mathrm{OMI} \mathrm{NO}$ retrieval. The OMI-derived surface $\mathrm{NO}_{2}$ and the in situ measurements exhibit a significant temporal correlation $(\mathrm{r}=0.3-0.8)$ for most stations, with higher correlation coefficients in polluted areas where boundary layer $\mathrm{NO}_{2}$ makes a larger contribution to the tropospheric column. The temporal and spatial correlation between satellite-derived and in situ concentrations for $\mathrm{NO}_{2}$ generally is even higher than previously found for $\mathrm{PM}_{2.5}$ over North America. The mean difference between OMI-derived surface $\mathrm{NO}_{2}$ and corrected in situ measurements in summer/ fall is $11 \%$ for rural, $-18 \%$ for suburban, and $-17 \%$ for urban sites of eastern North America. A somewhat larger difference $(-27 \%$ for rural, $-27 \%$ for suburban, and $-36 \%$ for urban sites) is observed in winter/fall when we have the most confidence in the corrected in situ measurements. The PSS- $\mathrm{NO}_{2}$ exhibits a similar bias with the OMI-derived surface $\mathrm{NO}_{2}$. These results are in line with the conclusions from validation of OMI tropospheric $\mathrm{NO}_{2}$ columns that OMI underestimates tropospheric columns by $14-30 \%$ [Celarier et al., 2008; Wenig et al., 2008; Bucsela et al., 2008] and furthermore suggest a seasonal variation in the bias.

[55] These comparisons illustrate the promise of our approach to derive ground-level concentration of $\mathrm{NO}_{2}$ from satellite observations. A more rigorous evaluation of satellite derived surface $\mathrm{NO}_{2}$ requires ground-based $\mathrm{NO}_{2}-$ specific measurements in a range of pollution levels over an 
extended period of time. Coordinated vertical profiles of $\mathrm{NO}_{2}$ from aircraft would test the relationship between the column and surface measurements. $\mathrm{A} \mathrm{NO}_{2}$ simulation at higher spatial resolution may better capture sharp horizontal gradients in the $\mathrm{NO}_{2}$ profile. This measurement capability would be extended with future satellite missions at urbanscale resolution from both geostationary and global orbits. Satellite remote sensing could become the most effective method to monitor surface $\mathrm{NO}_{2}$ in the United States considering the ongoing reductions in the number of ground-based $\mathrm{NO}_{2}$ monitors.

[56] Acknowledgments. We thank Ron Cohen and three anonymous reviewers for helpful comments that improved the manuscript. We are grateful to Michel Grutter, Armando Retama, and C.R. Ramos Villegas for their DOAS and $\mathrm{NO}_{\mathrm{x}}$ monitor data for Mexico City. We thank the OMI, AQS, and NAPS teams for making the data available. This work was supported by NASA's Atmospheric Composition Program and the Natural Sciences and Engineering Research Council of Canada. For the MCMA field campaign, the leadership of Mario and Luisa Molina and financial support from Comision Ambiental Metropolitana (Mexico), the National Science Foundation (ATM-308748, ATM-0528170, and ATM-0528227), and the Department of Energy (DE-FG02-05ER63980 and DE-FG0205ER63982) are gratefully acknowledged. This paper has been reviewed in accordance with the U.S. Environmental Protection Agency(tm)s (EPA) peer and administrative review policies and is approved for publication. The views expressed herein are solely those of the authors and do not represent the official policies or positions of the U.S. EPA.

\section{References}

Acarreta, J. R., J. F. de Haan, and P. Stammes (2004), Cloud pressure retrieval using the $\mathrm{O}_{2}-\mathrm{O}_{2}$ absorption band at $477 \mathrm{~nm}, J$. Geophys. Res., 109, D05204, doi:10.1029/2003JD003915.

Ackermann-Liebrich, U., et al. (1997), Lung function and long-term exposure to air pollutants in Switzerland: Study on air pollution and lung diseases in adults (SAPALDIA) team, Am. J. Respir. Crit. Care Med., $155,122-129$.

Barnard, J. C., E. G. Chapman, J. D. Fast, J. R. Schmelzer, J. R. Slusser, and R. E. Shetter (2004), An evaluation of the FAST-J photolysis algorithm for predicting nitrogen dioxide photolysis rates under clear and cloudy sky conditions, Atmos. Environ., 38, 3393-3403.

Beirle, S., U. Platt, M. Wenig, and T. Wagner (2003), Weekly cycle of $\mathrm{NO}_{2}$ by GOME measurements: A signature of anthropogenic sources, Atmos. Chem. Phys., 3, 2225-2232.

Bey, I., et al. (2001), Global modeling of tropospheric chemistry with assimilated meteorology: Model description and evaluation, J. Geophys. Res., 106, 23,073-23,096.

Boersma, K. F., E. J. Bucsela, E. J. Brinksma, and J. F. Gleason (2002), $\mathrm{NO}_{2}$, in OMI Algorithm Theoretical Basis Document, OMI Trace Gas Algorithms, ATB-OMI-04, Version 2.0, vol. 4, edited by K. Chance, NASA Distributed Active Archive Centers, Greenbelt, Md.

Boersma, K. F., H. J. Eskes, and E. J. Brinksma (2004), Error analysis for tropospheric $\mathrm{NO}_{2}$ retrieval from space, J. Geophys. Res., 109, D04311, doi:10.1029/2003JD003962.

Boersma, K. F., D. J. Jacob, H. J. Eskes, R. W. Pinder, J. Wang, and R. J. van der A (2008a), Intercomparison of SCIAMACHY and OMI tropospheric $\mathrm{NO}_{2}$ columns: Observing the diurnal evolution of chemistry and emissions from space, J. Geophys. Res., 113, D16S26, doi:10.1029/ 2007JD008816.

Boersma, K. F., et al. (2008b), Validation of OMI tropospheric $\mathrm{NO}_{2}$ observations during INTEX-B and application to constrain $\mathrm{NO}_{x}$ emissions over the eastern United States and Mexico, Atmos. Environ., 42(19), 4480-4497, doi:10.1016/j.atmosenv.2008.02.004.

Bovensmann, H., J. P. Burrows, M. Buchwitz, J. Frerick, V. V. Rozanov, K. V. Chance, and A. P. H. Goede (1999), SCIAMACHY: Mission objectives and measurement modes, J. Atmos. Sci., 56, 127-150.

Brook, J. R., R. T. Brunett, T. F. Dann, S. Cakmak, M. S. Goldberg, X. Fan, and A. J. Wheeler (2007), Further interpretation of the acute effect of nitrogen dioxide observed in Canadian time series studies, J. Expos. Sci. Environ. Epidemiol., 17, S36-S44.

Bucsela, E. J., E. A. Celarier, M. O. Wenig, J. F. Gleason, J. P. Veefkind, K. F. Boersma, and E. J. Brinksma (2006), Algorithm for $\mathrm{NO}_{2}$ vertical column retrieval from the Ozone Monitoring Instrument, IEEE Trans. Geosci. Remote Sens., 44, 1245-1258.

Bucsela, E. J., et al. (2008), Comparison of tropospheric $\mathrm{NO}_{2}$ in situ aircraft measurements with near-real-time and standard product data from the Ozone Monitoring Instrument, J. Geophys. Res., 113, D16S31, doi:10.1029/2007JD008838.

Burnett, R. T., D. Steib, J. R. Brook, S. Cakmak, R. Dales, M. Raizenne, R. Vincent, and T. Dann (2004), The short-term effects of nitrogen dioxide on mortality in Canadian cities, Arch. Environ. Health, 59, $228-237$.

Burrows, J. P., et al. (1999), The Global Ozone Monitoring Experiment GOME: Mission concept and first scientific results, J. Atmos. Sci., 56, $151-175$.

Celarier, E. A., et al. (2008), Validation of Ozone Monitoring Instrument nitrogen dioxide columns, J. Geophys. Res., 113, D15S15, doi:10.1029/ 2007JD008908.

Callies, J., E. Corpaccioli, M. Eisinger, A. Hahne, and A. Lefebvre (2000), GOME-2: Metop's second generation sensor for operational ozone monitoring, ESA Bull., 102, 28-36.

de Foy, B., E. Caetano, V. Magaña, A. Zitàcuaro, B. Càrdenas, A. Retama, R. Ramos, L. T. Molina, and M. J. Molina (2005), Mexico City basin wind circulation during the MCMA-2003 field campaign, Atmos. Chem. Phys., 7, 2267-2288.

Demerjian, K. L. (2000), A review of national monitoring networks in North America, Atmos. Environ., 34, 1861-1884.

Dobber, M. R., et al. (2008), Validation of Ozone Monitoring Instrument level $1 \mathrm{~b}$ data products, J. Geophys. Res., 113, D15S06, doi:10.1029/ 2007JD008665.

Duncan, B. N., R. V. Martin, A. C. Staudt, R. Yevich, and J. A. Logan (2003), Interannual and seasonal variability of biomass burning emissions constrained by satellite observations, J. Geophys. Res., 108(D12), 4100, doi:10.1029/2002JD002378.

Dunlea, E. J., et al. (2006), Technical note: Evaluation of standard ultraviolet absorption ozone monitors in a polluted urban environment, Atmos. Chem. Phys., 6, 3163-3180.

Dunlea, E. J., et al. (2007), Evaluation of nitrogen dioxide chemiluminescence monitors in a polluted urban environment, Atmos. Chem. Phys., 7, $2691-2704$.

Evans, M. J., and D. J. Jacob (2005), Impact of new laboratory studies of $\mathrm{N}_{2} \mathrm{O}_{5}$ hydrolysis on global model budgets of tropospheric nitrogen oxides, ozone and OH, Geophys. Res. Lett., 32, L09813. doi:10.1029/ 2005GL022469.

Fehsenfeld, F. C., et al. (1987), A ground-based intercomparison of NO, $\mathrm{NO}_{x}$, and $\mathrm{NO}_{y}$ measurement techniques, J. Geophys. Res., 92, 14,71014,722 .

Fehsenfeld, F. C., et al. (1990), Intercomparison of $\mathrm{NO}_{2}$ measurement techniques, J. Geophys. Res., 95, 3579-3597.

Finlayson-Pitts, F. C., and J. N. Pitts Jr. (Eds.) (1986), Atmospheric Chemistry: Fundamentals and Experimental Techniques, John Wiley, Hoboken, N. J.

Fontjin, A., A. J. Sabadell, and R. J. Ronco (1970), Homogeneous chemiluminescence measurement of nitric oxide with ozone, Anal. Chem., 42, $575-579$.

Gauderman, W. J., et al. (2000), Association between air pollution and lung function growth in southern California children, Am. J. Respir. Crit. Care Med., 162, 1383-1390.

Gauderman, W. J., et al. (2002), Association between air pollution and lung function growth in southern California children: Results from a second cohort, Am. J. Respir. Crit. Care Med., 166, 76-84.

Gerboles, M., F. Lagler, D. Rembges, and C. Brun (2003), Assessment of uncertainty of $\mathrm{NO}_{2}$ measurements by the chemiluminescence method and discussion of the quality objective of the $\mathrm{NO}_{2}$ European Directive, J. Environ. Monit., 5, 529-540.

Grosjean, D., and J. Harrison (1985), Response of chemiluminescence $\mathrm{NO}_{x}$ analyzers and ultraviolet ozone analyzers to organic air pollutants, Environ. Sci. Technol., 19, 862-865.

Guerova, G., I. Bey, J. L. Attie, R. V. Martin, J. Cui, and M. Sprenger (2006), Impact of transatlantic transport episodes on summertime ozone in Europe, Atmos. Chem. Phys., 6, 2057-2072.

Hirsch, R. M., and E. J. Gilroy (1984), Methods of fitting a straight line to data: Examples in water resources, Water Resour. Bull., 20, 705-711.

Hudman, R. C., et al. (2004), Ozone production in transpacific Asian pollution plumes and implications for ozone air quality in California, J. Geophys. Res., 109, D23S10, doi:10.1029/2004JD004974.

Hudman, R. C., et al. (2007), Surface and lightning sources of nitrogen oxides over the United States: Magnitudes, chemical evolution, and outflow, J. Geophys. Res., 112, D12S05, doi:10.1029/2006JD007912.

Jaeglé, L., L. Steinberger, R. V. Martin, and K. Chance (2005), Global partitioning of $\mathrm{NO}_{x}$ sources using satellite observations: Relative roles of fossil fuel combustion, biomass burning and soil emissions, Faraday Discuss., 130, 407-423, doi:10.1039/b502128f.

Leue, C., M. Wenig, T. Wagner, O. Klimm, U. Platt, and B. Jähne (2001), Quantitative analysis of $\mathrm{NO}_{2}$ emissions from Global Ozone Monitoring 
Experiment satellite image sequences, J. Geophys. Res., 106, $5493-$ 5505.

Levelt, P. F., E. Hilsenrath, G. W. Leppelmeier, G. B. J. van den Oord, P. K. Bhartia, J. Tamminen, J. F. de Haan, and J. P. Veefkind (2006a), Science objective of the Ozone Monitoring Instrument, IEEE Trans. Geosci. Remote Sens., 44, 1199-1208.

Levelt, P. F., G. H. J. van den Oord, M. R. Dobber, A. Malkki, H. Visser, J. de Vries, P. Stammes, J. O. V. Lundell, and H. Saari (2006b), The Ozone Monitoring Instrument, IEEE Trans. Geosci. Remote Sens., 44, $1093-1101$.

Li, Q., D. J. Jacob, J. W. Munger, R. M. Yantosca, and D. Parrish (2004), Export of $\mathrm{NO}_{y}$ from the North American boundary layer: Reconciling aircraft observations and global model budgets, J. Geophys. Res., 109 , D02313, doi:10.1029/2003JD004086.

Liu, Y., R. J. Park, D. J. Jacob, Q. Li, V. Kilaru, and J. A. Sarnat (2004), Mapping annual mean ground-level $\mathrm{PM}_{2.5}$ concentrations using Multiangle Imaging Spectroradiometer aerosol optical thickness over the contiguous United States, J. Geophys. Res., 109, D22206, doi:10.1029/ 2004JD005025.

Logan, J. A. (1983), Nitrogen oxides in the troposphere: Global and regional budgets, J. Geophys. Res., 88, 10,785-10,807.

Mannschreck, K., S. Gilge, C. Plass-Duelmer, W. Fricke, and H. Berresheim (2004), Assessment of the applicability of $\mathrm{NO}-\mathrm{NO}_{2}-\mathrm{O}_{3}$ photostationary state to long-term measurements at the Hohenpeissenberg GAW station, Germany, Atmos. Chem. Phys., 4, 1265-1277.

Martin, R. V., K. Chance, and D. J. Jacob (2002), An improved retrieval of tropospheric nitrogen dioxide from GOME, J. Geophys. Res., 107(D20), 4437, doi:10.1029/2001JD001027.

Martin, R. V., D. J. Jacob, K. Chance, T. P. Kurosu, P. I. Perner, and M. J Evans (2003a), Global inventory of nitrogen oxide emission constrained by space-based observations of $\mathrm{NO}_{2}$ columns, J. Geophys. Res., 108(D17), 4537, doi:10.1029/2003JD003453.

Martin, R. V., D. J. Jacob, R. M. Yantosca, M. Chin, and P. Ginoux (2003b), Global and regional decreases in tropospheric oxidants from photochemical effects of aerosols, J. Geophys. Res., 108(D3), 4097, doi:10.1029/ 2002JD002622.

Martin, R. V., et al. (2004a), Evaluation of GOME satellite measurements of tropospheric $\mathrm{NO}_{2}$ and $\mathrm{HCHO}$ using regional data from aircraft campaigns in the southeastern United States, J. Geophys. Res., 109, D24307, doi:10.1029/2004JD004869.

Martin, R. V., A. M. Fiore, and A. van Donkelaar (2004b), Space-based diagnosis of surface ozone sensitivity to anthropogenic emissions, Geophys. Res. Lett., 31, L06120, doi:10.1029/2004GL019416.

Martin, R. V., B. Sauvage, I. Folkins, C. E. Sioris, C. Boone, P. Bernath, and J. R. Ziemke (2007), Space-based constraints on the production of nitric oxide by lightning, J. Geophys. Res., 112, D09309, doi:10.1029/ 2006JD007831.

Martin, R. V., et al. (2006), Evaluation of space-based constraints on global nitrogen oxide emissions with regional aircraft measurements over and downwind of eastern North America, J. Geophys. Res., 111, D15308, doi:10.1029/2005JD006680

Matsumoto, J., N. Kosugi, A. Nishiyama, R. Isozaki, Y. Sadanaga, S. Kato, H. Bandow, and Y. Kajii (2006), Examination on photostationary state of $\mathrm{NO}_{\mathrm{x}}$ in the urban atmosphere in Japan, Atmos. Environ., 40, 3230-3239.

McClenny, W. A., E. J. Williams, R. C. Cohen, and J. Stutz (2002), Preparing to measure the effects of the $\mathrm{NO}_{x}$ SIP call-Methods for ambient air monitoring of $\mathrm{NO}, \mathrm{NO}_{2}, \mathrm{NO}_{y}$, and individual $\mathrm{NO}_{z}$ species, J. Air Waste Manage. Assoc., 52, 542.

Molina, L. T., et al. (2007), Air quality in North America's most populous city-Overview of MCMA-2003 Campaign, Atmos. Chem. Phys., 7, 2447-2473.

Munger, J. W., S. M. Fan, P. S. Bakwin, M. L. Goulden, A. H. Goldstein, A. S. Colman, and S. C. Wofsy (1998), Regional budgets for nitrogen oxides from continental sources: Variations of rates for oxidation and deposition with season and distance from source regions, J. Geophys. Res., 103, 8355-8368.

Neuman, J. A., L. G. Huey, T. B. Ryerson, and D. W. Fahey (1999), Study of inlet materials for sampling atmospheric nitric acid, Environ. Sci. Technol., 33, 1133-1136.

Ordóñez, C., A. Richter, M. Steinbacher, C. Zellweger, H. Nüß, and J. P. Burrows (2006), Comparison of 7 years of satellite-borne and groundbased tropospheric $\mathrm{NO}_{2}$ measurements around Milan, Italy, J. Geophys. Res., 111, D05310, doi:10.1029/2005JD006305.

Panella, M., V. Tommasini, M. Binotti, L. Palin, and G. Bona (2000), Monitoring nitrogen dioxide and its effects on asthmatic patients: Two different strategies compared, Environ. Monit. Assess., 63, 447-458.

Park, R. J., D. J. Jacob, B. D. Field, R. M. Yantosca, and M. Chin (2004), Natural and transboundary pollution influences on sulfate-nitrate-ammonium aerosols in the United States: Implications for policy, J. Geophys. Res., 109, D15204, doi:10.1029/2003JD004473.
Petritoli, A., et al. (2004), First comparison between ground-based and satellite-borne measurements of tropospheric nitrogen dioxide in the Po basin, J. Geophys. Res., 109, D15307, doi:10.1029/2004JD004547.

Platt, U. (1994), Differential optical absorption spectroscopy (DOAS), in Air Monitoring by Spectroscopic Techniques, edited by M. Sigrist, pp. 27-84, John Wiley, Hoboken, N. J.

Richter, A., J. P. Burrows, H. Nüß, C. Granier, and U. Niemeier (2005), Increase in tropospheric nitrogen dioxide levels over China observed from space, Nature, 437, 129-132.

Ryerson, T. B., E. J. Williams, and F. C. Fehsenfeld (2000), An efficient photolysis system for fast-response $\mathrm{NO}_{2}$ measurements, J. Geophys. Res., $105,26,447-26,461$

Samoli, E., et al. (2006), Short term effects of nitrogen dioxide and mortality: An analysis within the APHEA project, Eur. Respir. J., 27, 11291137.

San Martini, F. M., et al. (2006), Implementation of a Markov Chain Monte Carlo Method to inorganic aerosol modeling of observations from the MCMA-2003 Campaign. part I: Model description and application to the La Merced site, Atmos. Chem. Phys., 6, 4867-4888.

Sauvage, B., R. V. Martin, A. van Donkelaar, X. Liu, K. Chance, L. Jaeglé, P. I. Palmer, S. Wu, and T. M. Fu (2007), Remote sensed and in situ constraints on processes affecting tropical tropospheric ozone, Atmos. Chem. Phys., 7, 815-838.

Schaub, D., K. F. Boersma, J. W. Kaiser, A. K. Weiss, D. Folini, H. J. Eskes, and B. Buchmann (2006), Comparison of GOME tropospheric $\mathrm{NO}_{2}$ columns with $\mathrm{NO}_{2}$ profiles deduced from ground-based in situ measurements, Atmos. Chem. Phys., 6, 3211-3229.

Schindler, C., et al. (1998), Associations between lung function and estimated average exposure to $\mathrm{NO}_{2}$ in eight areas of Switzerland. The SAPALDIA Team. Swiss study of air pollution and lung diseases in adults, Epidemiology, 9, 405-411.

Schoeberl, M. R., et al. (2006), Overview of the EOS aura mission, IEEE Trans. Geosci. Remote Sens., 44, 1066-1074.

Singh, H. B., et al. (2007), Reactive nitrogen distribution and partitioning in the North American troposphere and lowermost stratosphere, J. Geophys. Res., 112, D12S04, doi:10.1029/2006JD007664.

Smith, B. J., M. Nitschke, L. S. Pilotto, R. E. Ruffin, D. L. Pisaniello, and K. J. Willson (2000), Health effects of daily indoor nitrogen dioxide exposure in people with asthma, Eur. Respir. J., 16, 879-885.

Steib, D., S. Judek, and R. T. Brunett (2003), Meta-analysis of time-series studies of air pollution and mortality: Update in relation to the use of generalized additive models, J. Air Waste Manage. Assoc., 53, 258-261. Steinbacher, M., C. Zellweger, B. Schwarzenbach, S. Bugmann, B. Buchmann, C. Ordòñez, A. S. H. Prevot, and C. Hueglin (2007), Nitrogen oxides measurements at rural sites in Switzerland: Bias of conventional measurement techniques, J. Geophys. Res., D11307, doi:10.1029/ 2006JD007971.

Stutz, J., B. Alicke, R. Ackermann, A. Geyer, S. H. Wang, A. B. White, E. J. Williams, C. W. Spicer, and J. D. Fast (2004), Relative humidity dependence of HONO chemistry in urban areas, J. Geophys. Res., D03307, doi:10.1029/2003JD004135.

U.S. Environmental Protection Agency (1975), Technical assistance document for the chemiluminescence measurement of nitrogen dioxide, technical report, Environmental Monitoring and Support Laboratory, U.S. Environmental Protection Agency, Research Triangle Park, NC 27711, EPA-600/4-75-003

U.S. Environmental Protection Agency (2001), National air quality and emissions trend report, technical report, Office of Air Quality Planning and Standardization, U.S. Environmental Protection Agency, Research Triangle Park, NC 27711, EPA-454/R-01-004.

van der A, R. J., D. H. M. Peters, H. Eskes, K. F. Boersma, M. Van Roozendael, I. De Smedt, and H. M. Kelder (2006), Detection of the trend and seasonal variation in tropospheric $\mathrm{NO}_{2}$ over China, J. Geophys. Res., 111, D12317, doi:10.1029/2005JD006594.

van Donkelaar, A., R. V. Martin, and R. J. Park (2006), Estimating groundlevel $\mathrm{PM}_{2.5}$ using aerosol optical depth determined from satellite remote sensing, J. Geophys. Res., 111, D21201, doi:10.1029/2005JD006996.

Volz-Thomas, A., H. W. Pätz, N. Houben, S. Konrad, D. Mihelcic, T. Klüpfel, and D. Perner (2003), Inorganic trace gases and peroxy radicals during BERLIOZ at Pabstthum: An investigation of the photostationary state of $\mathrm{NO}_{x}$ and $\mathrm{O}_{x}, J$. Geophys. Res., 108(D4), 8248, doi:10.1029/ 2001JD001255

Wang, Y., D. J. Jacob, and J. A. Logan (1998), Global simulation of tropospheric $\mathrm{O}_{3}-\mathrm{NO}_{x}$-hydrocarbon chemistry, 1. Model formulation, J. Geophys. Res., 103, 10,713-10,726.

Wang, Y. X., M. B. McElroy, T. Wang, and P. I. Palmer (2004), Asian emissions of $\mathrm{CO}$ and $\mathrm{NO}_{x}$ : Constraints from aircraft and Chinese station data, J. Geophys. Res., 109, D24304, doi:10.1029/2004JD005250.

Wang, Y. X., M. B. McElroy, K. F. Boersma, H. J. Eske, and J. Veefkind (2007a), Traffic restrictions associated with the Sino-African Summit: 
Reductions of $\mathrm{NO}_{x}$ detected from space, Geophys. Res. Lett., 34, L08814, doi:10.1029/2007GL029326.

Wang, Y. X., M. B. McElroy, R. V. Martin, D. G. Streets, Q. Zhang, and T.-M. Fu (2007b), Seasonal variability of $\mathrm{NO}_{x}$ emissions over east China constrained by satellite observations: Implications for combustion and microbial sources, J. Geophys. Res., 112, D06301, doi:10.1029/ 2006JD007538.

Wenig, M. O., A. M. Cede, E. J. Bucsela, E. A. Celarier, F. K. Boersma, J. P. Veefkind, E. J. Brinksma, J. F. Gleason, and J. R. Herman (2008), Validation of OMI tropospheric $\mathrm{NO}_{2}$ column densities using direct-sun mode Brewer measurements at NASA Goddard Space Flight Center, J. Geophys. Res., 113, D16S45, doi:10.1029/2007JD008988.

Wild, O., X. Zhu, and M. J. Prather (2000), Fast-J: Accurate simulation of in- and below-cloud photolysis in tropospheric chemical models, J. Atmos. Chem., 37, 245-282.

Winer, A. M., J. W. Peters, J. P. Smith, and J. N. Pitts Jr. (1974), Response of commercial chemiluminescent $\mathrm{NO}-\mathrm{NO}_{2}$ analyzers to other nitrogen containing compounds, Environ. Sci. Technol., 8, 1118-1121.

Yienger, J. J., and H. Levy (1995), Empirical model of global soil biogenic $\mathrm{NO}_{x}$ emissions, J. Geophys. Res., 100, 11,447-11,464.

Zellweger, C., M. Ammann, B. Buchmann, P. Hofer, M. Lugauer R. Rüttimann, N. Streit, E. Weingartner, and U. Baltensperger (2000), Summertime $\mathrm{NO}_{y}$ speciation at the Jungfraujoch, $3580 \mathrm{~m}$ above sea level, Switzerland, J. Geophys. Res., 105, 6655-6667.
Zhang, Q., et al. (2007), $\mathrm{NO}_{x}$ emission trends for China, 1995-2004: The view from the ground and the view from space, J. Geophys. Res., 112, D22306, doi:10.1029/2007JD008684.

E. Bucsela, SRI International, Menlo Park, CA 94025, USA. (bucsela@ ix.netcom.com)

E. A. Celarier, SGT, Inc., 7701 Greenbelt Road, Suite 400, Greenbelt, MD 20770, USA. (edward.a.celarier@nasa.gov)

E. J. Dunlea, Cooperative Institute for Research in Environmental Sciences, University of Colorado at Boulder, UCB 216, Boulder, CO 80309, USA. (edward.dunlea@colorado.edu)

L. N. Lamsal, R. V. Martin, and A. van Donkelaar, Department of Physics and Atmospheric Science, Dalhousie University, James Dunn Building, Room 102, Halifax NS, Canada B3H 3J5. (lok.lamsal@fizz. phys.dal.ca; randall.martin@dal.ca; aaron.van.donkelaar@dal.ca)

J. P. Pinto, U.S. Environmental Protection Agency, National Center for Environmental Assessment, Research Triangle Park, NC 27711, USA (pinto.joseph@epamail.epa.gov)

M. Steinbacher, Laboratory for Air Pollution/Environment Technology, Empa, Swiss Federal Institute for Materials Science and Technology, CH-8600, Dübendorf, Switzerland. (martin.steinbacher@empa.ch) 